\title{
Interleukin-6 selectively induces drug metabolism to potentiate the genotoxicity of dietary carcinogens in mammary cells
}

\author{
Durr-e-shahwar Malik ${ }^{1} \cdot$ Rhiannon M. David ${ }^{1,2} \cdot$ Nigel J. Gooderham $^{1}$ (D)
}

Received: 12 July 2019 / Accepted: 2 September 2019 / Published online: 12 September 2019

(c) The Author(s) 2019

\begin{abstract}
Breast cancer is the most commonly diagnosed malignancy in females, the etiology being multifactorial and includes the role of lifestyle exposure to DNA-damaging chemicals such as dietary carcinogens benzo (a) pyrene (BaP) and 2-amino-1-methyl6-phenylimidazo [4, 5-b] pyridine (PhIP). Both compounds require cytochrome P450 (CYP)-mediated metabolic activation to DNA-damaging species, and both induce transcriptional responses through the nuclear receptors Aryl hydrocarbon receptor $(\mathrm{AhR})$ and estrogen receptor $\alpha(\mathrm{ER} \alpha)$. $\mathrm{BaP}$ and $\mathrm{PhIP}$ are mammary carcinogens in rodents. Clinically, circulating IL-6 expression is linked with poor prognosis of cancer and $35 \%$ of the deaths in breast cancer are linked with inflammation. The objective of this work was to investigate the molecular toxicology and local activation of BaP and PhIP in the presence of IL-6. Our laboratory has previously reported that miR27b can regulate CYP1B1 expression in colorectal cells, here we have investigated if this mechanism is working in mammary cell models, MCF-7 and MDA-MB-231 cells. Treatment (24 h) of cells with $\mathrm{BaP}(10 \mathrm{nM}-10 \mu \mathrm{M})$ and $\mathrm{PhIP}(100 \mathrm{nM}-100 \mu \mathrm{M})$ significantly induced genetic damage (micronuclei formation) in a dose-dependent manner in both cell lines. This effect was potentiated in the presence of human IL- 6 at concentrations reported to be expressed in clinical breast cancer. On its own, IL-6 treatment failed to induce micronuclei frequency above the control levels in these cells. Compared to BaP or PhIP treatment alone, IL-6 plus BaP or PhIP selectively induced CYP1B1 significantly in both cell lines. Additionally, miR27b expression was downregulated by IL-6 treatments and transfection with miR27b inhibitor confirmed that miR27b is a regulator of CYP1B1 in both cell lines. These data show that BaP- and PhIPinduced DNA damage in mammary cells is potentiated by the inflammatory cytokine IL- 6 and that inflammation-induced CYP expression, specifically CYP1B1 via miR27b, is responsible for this effect.
\end{abstract}

Keywords Benzo(a)pyrene $\cdot 2$-Amino-1-methyl-6-phenylimidazo[4,5-b]pyridine $\cdot$ IL-6 $\cdot$ Inflammation $\cdot$ miRNA $\cdot$ Human mammary cells $\cdot$ Genotoxicity

\section{Introduction}

Epidemiological studies suggest that chronic inflammation increases the susceptibility of individuals to various types of cancer and is linked with $15-20 \%$ of all deaths from cancer worldwide (Bray et al. 2004; Mantovani et al. 2008). IL-6 is one of the most consistently up-regulated inflammatory mediators in breast tumors and is linked with

Nigel J. Gooderham

n.gooderham@imperial.ac.uk

1 Metabolism, Digestion and Reproduction, Imperial College London, London SW7 2AZ, UK

2 Present Address: Genetic Toxicology, Discovery Safety, Drug Safety and Metabolism, IMED Biotech Unit, AstraZeneca, Cambridge, UK malignant transformation of inflammatory breast cancer (IBC), an aggressive form of breast cancer (Zhang and Adachi 1999; Bachelot et al. 2003; Sanguinetti et al. 2015). The role of cytokines and particularly IL-6 to increase the proliferation, survival, epithelial-mesenchymal transition, invasion, and metastasis has been reported (Zhang and Adachi 1999; Fouad et al. 2014), however, its potential role in the early stages of carcinogenesis is less well understood. Oxidative stress, impairment of p53-dependent protective responses and modulation of various signaling pathways are linked with mutations involved in carcinogenesis associated with chronic inflammation and upregulation of cytokines (Lu et al. 2006). IL-6 can also affect the expression of specific CYP450s that can further influence carcinogenesis through altered bio-activation of various environmental carcinogens (Muntane-Relat et al. 1995). 
In the main, studies on the effect of infection and inflammation on xenobiotic metabolism and activation report the suppression of CYP450s by cytokines such as IL-6 in liver and hepatocytes (Deloria et al. 1985; Gooderham and Mannering 1986; Morgan 1989; Muntane-Relat et al. 1995; Renton 2001, 2004; Aitken et al. 2006), however, recent studies in non-hepatic cell lines have demonstrated up-regulation of selective CYPs by IL-6 (Kurzawski et al. 2012; Patel et al. 2014; Patel and Gooderham 2015a, b), suggesting variation in response in a tissue-specific manner.

As much as $90-95 \%$ of cancers are reported to be preventable and have their origin from environment and lifestyle (Anand et al. 2008). Almost 25-30\% of the cancer-related deaths are ascribed to tobacco, while $30-35 \%$ are linked to diet (Gooderham et al. 1996; Willett 2000; Barrett et al. 2003). Increased consumption of red meat and exposure to smoke in western lifestyle is linked with increased incidence of breast cancer (Zhu et al. 2003; Linos et al. 2007; Wu et al. 2009; Ronco et al. 2011). Benzo(a)pyrene (BaP) and 2-amino-1-methyl-6-phenylimidazo [4,5-b]-pyridine ( $\mathrm{PhIP})$ are commonly occurring environmental carcinogens (Sinha and Rothman 1999; Gooderham et al. 2002; Zheng and Lee 2009). $\mathrm{BaP}$ is present in tobacco smoke, pollution and in grilled food (Davis 1968; Kazerouni et al. 2001). PhIP is the most abundant heterocyclic amine in cooked meat (Zheng and Lee 2009; Felton et al. 1991; Lynch et al. 1992; Murray et al. 1993; Gooderham et al. 1997). BaP and PhIP are pro-carcinogens and are activated by CYP1 family A1, A2 and $\mathrm{B} 1$ enzymes into their genotoxic derivatives that bind covalently with DNA, disrupting the double helical structure leading to DNA damage (Strom and Michalopoulos 1982; Heussen et al. 1990; Boobis et al. 1994; Zhao et al. 1994; Kranendonk et al. 1998; Lynch et al. 1998; Gooderham et al. 2002, 2007). Activation of these CYP enzymes can increase the mutagenicity of various pro-carcinogens.

The regulation of CYP1 family enzymes is generally thought to be under control of inducible promoter regions, however, other epigenetic mechanisms are also reported to contribute to expression. In particular, microRNA (miRNA) has been shown to post-transcriptionally control numerous gene targets. MicroRNAs are a class of non-coding RNA that have powerful post-transcriptional gene expression regulation properties and have been found to be important contributors to the development of cancer. MiRNA are shown to regulate various genes including tumor suppressor and oncogenes that are involved in the progression of breast cancer (Bachour and Bennett 2011). Moreover, they can regulate the expression of CYP enzymes (Patel et al. 2014; Patel and Gooderham 2015a, b; Rieger et al. 2015). In line with this, our current study shows that IL-6 can alter CYP activation and genotoxicity of environmental pro-carcinogens and this includes regulation of miRNA expression.

\section{Methods}

\section{Cell culture and treatment}

The human breast adenocarcinoma MCF-7 (ER- $\left.\alpha^{+}\right)$and MDA-MB-231 $\left(\right.$ ER- $\left.\alpha^{-}\right)$cell lines were purchased from ATCC (LGC Prochem, Middlesex, UK) and were grown in minimum essential medium (MEM) (GIBO, Life technologies, Paisley, UK) supplemented with $10 \%$ fetal bovine serum (FBS), penicillin (100 units/ml) and streptomycin $(100 \mu \mathrm{g} / \mathrm{ml})$ and $2 \mathrm{mM} \mathrm{L}$-glutamine. Cells were cultured routinely in $75 \mathrm{~cm}^{2}$ flasks in a humidified incubator at $37^{\circ} \mathrm{C}, 5 \%$ $\mathrm{CO}_{2}$. Prior to treatment, cells (MCF-7 and MDA-MB-231) at a density of 25,000 cells/well in 24 -well plates, were cultured in MEM supplemented with 5\% dextran-coated charcoal-stripped FBS (Stripped media) for $72 \mathrm{~h}$. Cells were treated with PhIP $(0-100 \mu \mathrm{M}$, Toronto Research Chemicals Inc., Toronto, Canada) or BaP $(0-10 \mu \mathrm{M})$, dissolved in dimethyl sulphoxide (DMSO) or IL-6 (0-20,000 pg/ml, Humankine, Sigma-Aldrich, Dorset, UK) dissolved in PBS with $0.1 \%$ human serum albumin (Sigma-Aldrich). In some experiments, cells were treated simultaneously with IL-6 and $\mathrm{BaP}$ or $\mathrm{PhIP}$.

\section{Cytotoxicity and micronucleus assay}

Cytotoxicity and micronucleus (MN) assays were performed according to OECD guidelines adapted to MCF-7 and MDAMB-231 cells. Briefly, cells were seeded at a density of $5 \times 10^{4}$ cells per well in 24-well plate. Cells were treated with $\mathrm{BaP}$ or PhIP or IL-6 or in combination as described in the text. Following treatment with chemicals and harvesting $(48 \mathrm{~h})$, cells were trypsinised, the cell concentration adjusted to $2 \times 10^{5}$ and re-suspended in serum-free $R_{0}$ (serum-free media) with $2 \%$ pluronic acid medium (GIBCO, Life technologies) and cytotoxicity was determined by counting cells in a haemocytometer with TrypanBlue exclusion (GIBCO, Life technologies). For the MN assay, cells were spread on a microscope slide using a cytospin. Cells at a density of $2 \times 10^{4}$ cells per slide were fixed with $100 \%$ methanol and stained for $60 \mathrm{~s}$ with acridine orange $(0.1 \mathrm{mg} / \mathrm{ml}$ dissolved in PBS, Sigma-Aldrich). Frequency of MN was scored in 2000 cells per sample and three biological replicates were performed per treatment. Etoposide $(1.25 \mu \mathrm{M})$ was used as a positive control.

\section{Reverse transcription quantitative polymerase chain reaction ( $R T-q P C R)$}

Following treatment, cells were lysed using TRIZOL reagent and chloroform $(0.2 \mathrm{ml})$ was added to each sample and 
centrifuged $12,000 \times g\left(10 \mathrm{~min}, 2-8{ }^{\circ} \mathrm{C}\right)$. The upper aqueous phase was transferred to a fresh tube and $5 \mu \mathrm{g}$ of RNase-free glycogen (as carrier to aqueous phase) and $0.5 \mathrm{ml}$ isopropyl alcohol were added to precipitate RNA and incubated $\left(37^{\circ} \mathrm{C}, 10 \mathrm{~min}\right)$. Following incubation, lysates were centrifuged at $12,000 \times g\left(10 \mathrm{~min}, 2-8{ }^{\circ} \mathrm{C}\right)$. The gel-like pellet was washed with ethanol and re-dissolved in RNase-free water with heating $\left(55-60{ }^{\circ} \mathrm{C}\right)$. Extracted RNA was quantified by UV spectroscopy (UV-Vis Nano-spectrophotometer, Implen, Essex, UK) and purity was assessed from $260 / 280$ to $260 / 230 \mathrm{~nm}$ ratios. Reverse transcription (RT) of extracted RNA (100-500 ng) was completed according to manufacturer's protocol (Invitrogen) and qPCR was performed using predesigned Taqman gene expression assays and FAST PCR master mix (Taqman, Applied Biosystems, Life technologies) using a StepOnePlus fast real-time PCR system (Applied Biosystems, Life technologies). Target gene expression was normalized to GAPDH and quantified using the delta-Ct method (Livak and Schmittgen 2001).

\section{Ethoxyresorufin-0-deethylase}

Ethoxyresorufin- $O$-deethylase (EROD) assay was used as a measure of CYP1 family activity. Following treatment, 7-ethoxyresorufin $(8 \mathrm{mM})$ was added to cells $\left(2 \times 10^{6}\right.$ in $1 \mathrm{ml}$ of media) to give a final concentration of $8 \mu \mathrm{M}$. The plate was incubated at $37{ }^{\circ} \mathrm{C}$ for $90 \mathrm{~min}$ in a fluorescent plate reader (BMG POLARstar Galaxy Labtech, Ortenberg, Germany) and read at $10 \mathrm{~min}$ intervals at $37{ }^{\circ} \mathrm{C}$ at $\lambda$ excitation ( $\lambda$ ex) $560 \mathrm{~nm}$ and $\lambda$ emission $(\lambda \mathrm{em}) 590 \mathrm{~nm}$. A resorufin standard curve was run by adding stock solution to give final concentrations of $20 \mathrm{nM}, 10 \mathrm{nM}, 5 \mathrm{nM}, 2 \mathrm{nM}, 1 \mathrm{nM}$, $0.5 \mathrm{nM}$. Subsequently, total protein was extracted from cells collected in each assay and quantified. Enzyme activity was expressed as pmol resorufin formed per min per $\mathrm{mg}$ protein. Rat liver S9 fraction which expresses high levels of CYP was used as a positive control for the assay. Cells were collected and centrifuged at $1500 \mathrm{rpm}$ and washed with serum-free media $(R o)$. The pellet was stored at $-80{ }^{\circ} \mathrm{C}$. Immunoprecipitation (IP) lysis buffer $(200 \mu \mathrm{l})$ was added, followed by vortexing, sonication $(30 \mathrm{~s})$, incubation on ice (30 $\mathrm{min})$ and finally centrifugation to remove debris $(10,000 \mathrm{rpm}$ at $2-4{ }^{\circ} \mathrm{C}$ for $5 \mathrm{~min}$ ). Bicinchoninic acid (BCA) assay (Pierce, ThermoScientific) was performed to determine protein concentration according to manufacturer's instructions.

\section{Transfection with miRNA inhibitor}

Cells were seeded at a density of $1 \times 10^{5}$ cells/well in 24-well plate and allowed to settle overnight in 10\% FBS MEM medium (no penicillin/streptomycin). Following overnight incubation, media was replaced with $400 \mu \mathrm{l} /$ well opti-MEM media (Gibco, Life Technologies), followed by the addition of $150 \mu \mathrm{l} /$ well of Opti-MEM containing $2.5 \mu \mathrm{l}$ of Lipofectamine 2000 reagent and $2.5 \mu \mathrm{l}$ of $20 \mu \mathrm{M}$ stock of miRNA inhibitor or miRIDIAN miRNA negative control (Dharmacon, UK). Transfected MCF-7 and MDA-MB-231 cells were incubated at $37{ }^{\circ} \mathrm{C}, 5 \% \mathrm{CO}_{2}$ for $24 \mathrm{~h}$ and $48 \mathrm{~h}$, respectively, before harvesting RNA with Trizol reagent (Invitrogen).

\section{Statistical analysis}

The difference in treatments vs control was compared by one-way analysis of variance (ANOVA) followed by a Dunnett's post-test. Data were obtained from measurements made in at least three independent cultures and presented as a mean \pm standard error (SEM). Pearson's correlation coefficient test was used for correlation analysis (GraphPad Prism 5, GraphPad Software Inc., La Jolla, CA, USA).

\section{Results}

\section{Effect of BaP, PhIP and IL-6 on CYP1 family enzyme expression}

The expression of CYP1A1, CYP1A2 and CYP1B1 was inducible by $\mathrm{BaP}$ treatment in a dose-dependent manner; the magnitude of the induction was greatest for CYP1A1 and CYP1B1 in both cell lines (Table 1). In contrast, PhIP failed to induce expression of CYP1A1 but did induce the expression of CYP1A2 and CYP1B1 in both cell lines, albeit to a lesser extent than CYP induction by $\mathrm{BaP}$.

Following $24 \mathrm{~h}$ treatment of MCF7 and MDA-MB-231 cell lines with IL-6 (0-20 ng/ml), little change in CYP1A1 and CYP1A2 expression was observed, however, a dosedependent induction in CYP1B1 was seen in both cell lines (Fig. 1e and f). Compared to control, the lowest concentration of IL-6 that significantly induced CYP1B1 in both cell lines was $500 \mathrm{pg} / \mathrm{ml}$ (Fig. 1e and f). This is at the higher levels of circulating IL-6 in cancer patients, reported to be between 10 and $500 \mathrm{pg} / \mathrm{ml}$ (Blay et al. 1992; Goswami et al. 2013; Brouwers et al. 2015), but below the IL-6 levels reported to be present in breast tumor tissue (3-5 ng/g tumor) (Ueno et al. 2000; Knupfer et al. 2004; Knupfer and Preiss 2007). Thus, in subsequent co-culture experiments we used a maximum of $500 \mathrm{pg} / \mathrm{ml} \mathrm{IL-6.} \mathrm{It} \mathrm{is} \mathrm{worth} \mathrm{noting}$ here that most reported mechanistic studies with mammary cancer cells have used a concentration of IL-6 in the $\mathrm{ng} / \mathrm{ml}$ range (Yamashita et al. 1993; Hobisch et al. 2001; Knupfer and Preiss 2007; Oh et al. 2011; Deshmukh et al. 2015).

Whilst IL-6 is reported to down-regulate the expression of CYP1A1 and CYP1A2 in liver cells (Muntane-Relat et al. 1995), recent studies using colorectal cells have shown that IL-6 upregulates the transcription of CYP1B1 (Patel et al. 
Table 1 Fold change in mRNA expression compared to vehicle control following $24 \mathrm{~h}$ treatment with $\mathrm{BaP}$ and PhIP in mammary cancer cell lines

\begin{tabular}{|c|c|c|c|c|c|c|}
\hline \multirow[t]{2}{*}{ Treatments } & \multicolumn{3}{|l|}{ MCF-7 } & \multicolumn{3}{|c|}{ MDA-MB-231 } \\
\hline & CYP1A1 & CYP1A2 & CYP1B1 & CYP1A1 & CYP1A2 & CYP1B1 \\
\hline $\mathrm{BaP} 10 \mathrm{nM}$ & $2.5 \pm 0.5$ & $1.3 \pm 0.2$ & $2.9 \pm 0.5$ & $2.6 \pm 0.3$ & $2.0 \pm 0.1$ & $1.3 \pm 0.1$ \\
\hline $\mathrm{BaP} 100 \mathrm{nM}$ & $8 \pm 0.9$ & $2.3 \pm 1.1$ & $10.3 \pm 2$ & $17.1 \pm 1.5$ & $3.5 \pm 0.6$ & $4.7 \pm 1.7$ \\
\hline $\mathrm{BaP} 1 \mu \mathrm{M}$ & $24.1 \pm 2.2$ & $7.9 \pm 0.9$ & $20.5 \pm 3$ & $27.1 \pm 1.7$ & $6.9 \pm 0.8$ & $14.2 \pm 3.4$ \\
\hline $\mathrm{BaP} 10 \mu \mathrm{M}$ & $34.2 \pm 3.1$ & $11 \pm 0.9$ & $28 \pm 1.7$ & $38.9 \pm 4.2$ & $11.4 \pm 1.4$ & $29.2 \pm 3.6$ \\
\hline PhIP100 nM & $1.1 \pm 0.6$ & $2.1 \pm 0.5$ & $1.7 \pm 0.4$ & $0.5 \pm 0.3$ & $1.1 \pm 0.5$ & $0.9 \pm 0.2$ \\
\hline $\mathrm{PhIP} 1 \mu \mathrm{M}$ & $1.1 \pm 0.6$ & $2.3 \pm 0.4$ & $2.6 \pm 0.5$ & $0.3 \pm 0.2$ & $4.3 \pm 0.5$ & $1.6 \pm 0.4$ \\
\hline $\mathrm{PhIP} 10 \mu \mathrm{M}$ & $1.1 \pm 0.3$ & $3.5 \pm 0.9$ & $3.5 \pm 0.7$ & $0.6 \pm 0.4$ & $4.6 \pm 1$ & $1.6 \pm 0.2$ \\
\hline PhIP100 $\mu \mathrm{M}$ & $1.7 \pm 0.1$ & $5.6 \pm 0.5$ & $6.9 \pm 1.5$ & $0.6 \pm 0.2$ & $5.5 \pm 1$ & $2.7 \pm 0.3$ \\
\hline
\end{tabular}

Data are fold change compared to the DMSO control presented as a mean \pm SEM of at least three independent cultures
2014; Patel and Gooderham 2015a, b). The studies reported here extend this observation to breast cancer cells.

\section{Can IL-6 augment BaP/PhIP-mediated CYP induction?}

In addition to their ability to induce the expression of the CYP1 family enzymes, both $\mathrm{BaP}$ and PhIP are activated to their genotoxic metabolites by CYP1A1, CYP1B1 and CYP1A2 enzymes. Since IL-6 treatment of MCF-7 and MDA-MB-231 cells also induced CYP1B1, we examined the effect of co-treatment of MCF-7 and MDA-MB-231 cells with IL-6 and BaP/PhIP. Co-treatments of IL-6 with BaP elevated CYP1B1 gene expression significantly above that induced by $\mathrm{BaP}$ alone in both in MCF-7 (Fig. 2c) and MDAMB-231 (Fig. 3c), but there was no similar additional induction of CYP1A1 and CYP1A2 (Figs. 2 and 3) compared to $\mathrm{BaP}$ or $\mathrm{PhIP}$ alone, in either cell line.

CYP1 family enzyme activity can be assessed by monitoring ethoxyresorufin- $O$-deethylase activity (EROD) (Crespi et al. 1997). EROD activity was increased with co-treatment of $\mathrm{BaP}$ and IL- 6 compared to $\mathrm{BaP}$ treatment alone in both cell lines (Fig. 4a and b). Increase in EROD activity with increasing dose of $\mathrm{BaP}$ was seen up to $1 \mu \mathrm{M}$, thereafter the EROD decreased (Fig. 4a and b). This decrease in activity was likely due to competitive inhibition of $\mathrm{BaP}$ and ethoxyresorufin for CYP1 enzymes (Petrulis and Bunce 1999). In the IL-6 plus PhIP combination experiment, an increase in EROD activity was seen in the MCF-7 cell line (Fig. 4c) but not in the MDA-MB-231 cell line. This pattern of response was similar to that observed for CYP induction in the two cell lines.

\section{Can IL-6 increase the genotoxicity of dietary carcinogens?}

Since IL-6 treatment resulted in an overall increase in CYP1B1 enzyme expression and CYP1 family enzyme activity (EROD), then it is possible that co-treatment with IL-6 and BaP or PhIP could lead to enhanced genotoxicity of the carcinogens. In initial experiments, we established a dose range of $\mathrm{BaP} / \mathrm{PhIP}$ that induced a genotoxic response with minimal cell death in mammary cancer cell lines (Table 2). To assess genotoxicity, we used a micronucleus assay.

Both $\mathrm{BaP}$ and PhIP were genotoxic in both cell lines, as assessed in the micronucleus assay (Table 2). Over the dose range employed, neither carcinogen was excessively toxic and cytotoxicity levels were within OECD guidelines for the assay. Therefore, to study the effect of co-treatment with IL-6 (500 pg/ml), BaP was used at $100 \mathrm{nM}$ to $10 \mu \mathrm{M}$ and PhIP was used at $100 \mathrm{nM}$ to $100 \mu \mathrm{M}$. The cytotoxicity for all combination experiments did not differ significantly from the negative vehicle control or positive control (etoposide, $1.25 \mu \mathrm{M})$ (Fig. 5). In the presence of IL-6 with BaP or $\mathrm{PhIP}$, a significant increase in $\mathrm{MN}$ formation was seen compared to $\mathrm{BaP}$ or PhIP treatments alone. This IL-6-mediated increase was reproduced in both cell lines. (Fig. 6), however, IL-6 alone did not induce genotoxicity in either cell line (Fig. 6). Etoposide (positive control) is a direct acting genotoxin that does not require metabolic activation and has a completely different mechanism of action (topoisomerase II inhibition) to induce DNA damage, compared to $\mathrm{BaP} /$ PhIP. In co-treatments of IL-6 and etoposide, no change in MN formation was observed suggesting IL- 6 selectively affects the metabolic activation of pro-carcinogens (Fig. 6). Since IL-6 does not affect the expression of CYP1A1/2 but does induce CYP1B1 (Figs. 2 and 3), it seems likely that enhanced MN frequency is due to the increased metabolic activity of CYP1B1.

\section{Can miR27b regulate IL-6?}

Recently, our laboratory has demonstrated that in colorectal cells IL6 can post-transcriptionally regulate CYP1B 1 expression through miR27b downregulation via a DNA methylation pathway (Patel et al. 2014). We therefore 
A

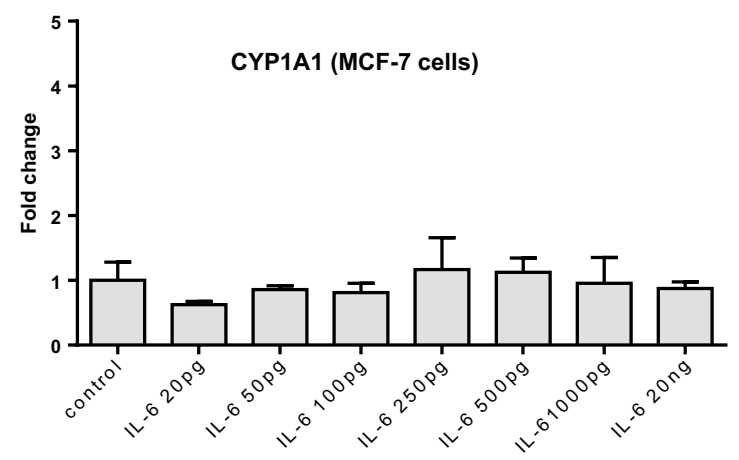

C
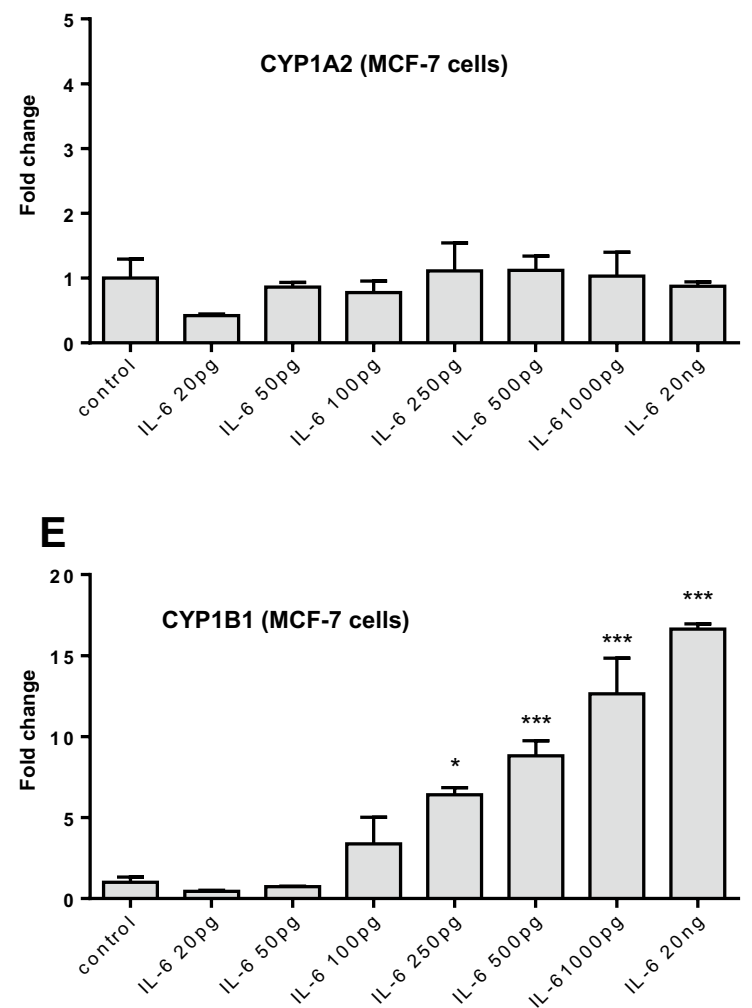

Fig. 1 Effect of IL-6 on the induction of CYP1 enzymes: MCF-7 (a, c, e) and MDA-MB-231 (b, d, f) cells were treated for $24 \mathrm{~h}$ with IL-6 and the induction of CYP1A1 (a, b), CYP1A2 (c, d) and CYP1B1 (e, f) was measured by RT-qPCR. Data were normalized to expression of GAPDH and are shown relative to control $(0.1 \%$ albumin

explored the possibility that this mechanism may also apply to mammary cells. Treatment of MCF-7 cells with $\mathrm{BaP}$ or $\mathrm{PhIP}$ alone failed to affect miR27b expression, whereas treatment with IL-6 alone and in combination with BaP and $\mathrm{PhIP}$ profoundly reduced miR27b expression (Fig. 7a and $\mathrm{c}$ ). In contrast in MBA-MD-231 cells, both $\mathrm{BaP}$ and IL-6 alone reduced expression of miR27b but PhIP alone did not (Fig. $7 b$ and d). This suggests that IL-6 can regulate
B

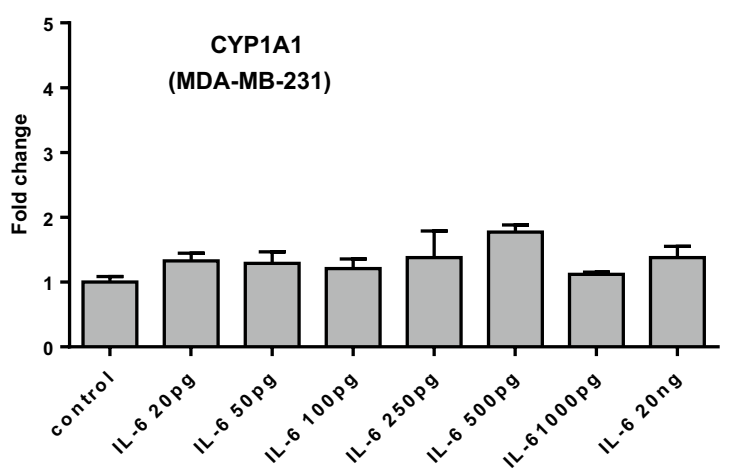

D

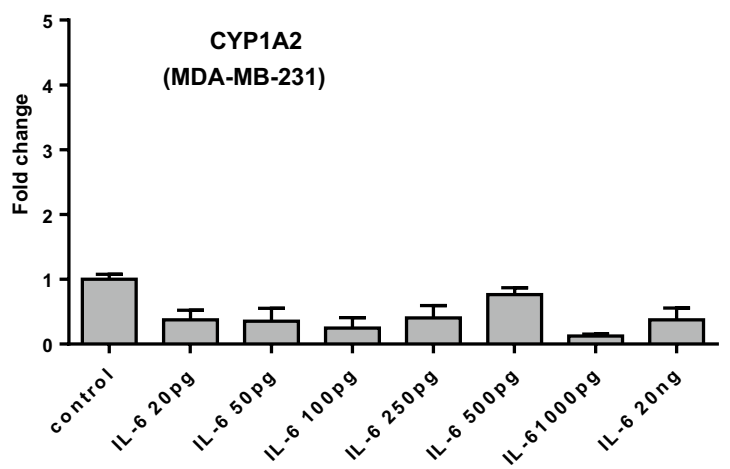

$\mathbf{F}$

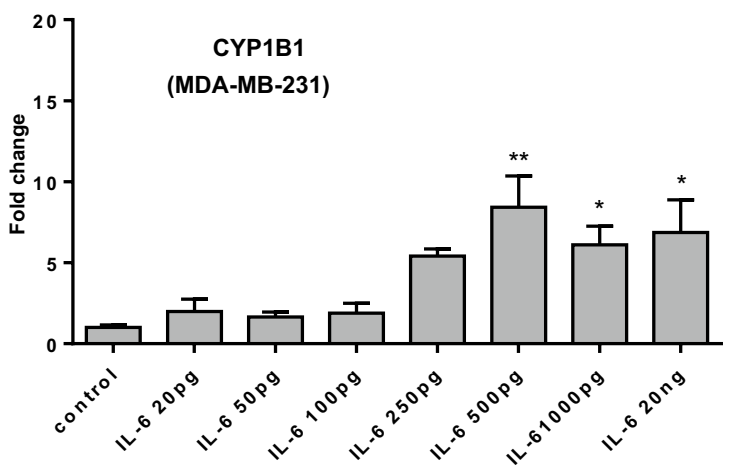

in PBS). Statistically significant differences were calculated using one-way ANOVA with a Dunnett's post-test (GraphPad Prism 5) $(* * * p<0.001, * * p<0.01, * p<0.05)$. Data are presented as a mean of at least three independent cultures. Error bars represent the SEM

the CYP1B1-mediated genotoxicity of $\mathrm{BaP}$ and $\mathrm{PhIP}$ via miR27b down-regulation in both cell lines.

\section{BaP induction of IL-6}

This selective effect of $\mathrm{BaP}$ (but not PhIP) on miR27b expression in MDA-MB-231 cells (Fig. 7b and d) is potentially of significance. $\mathrm{BaP}$ is known to induce inflammation 

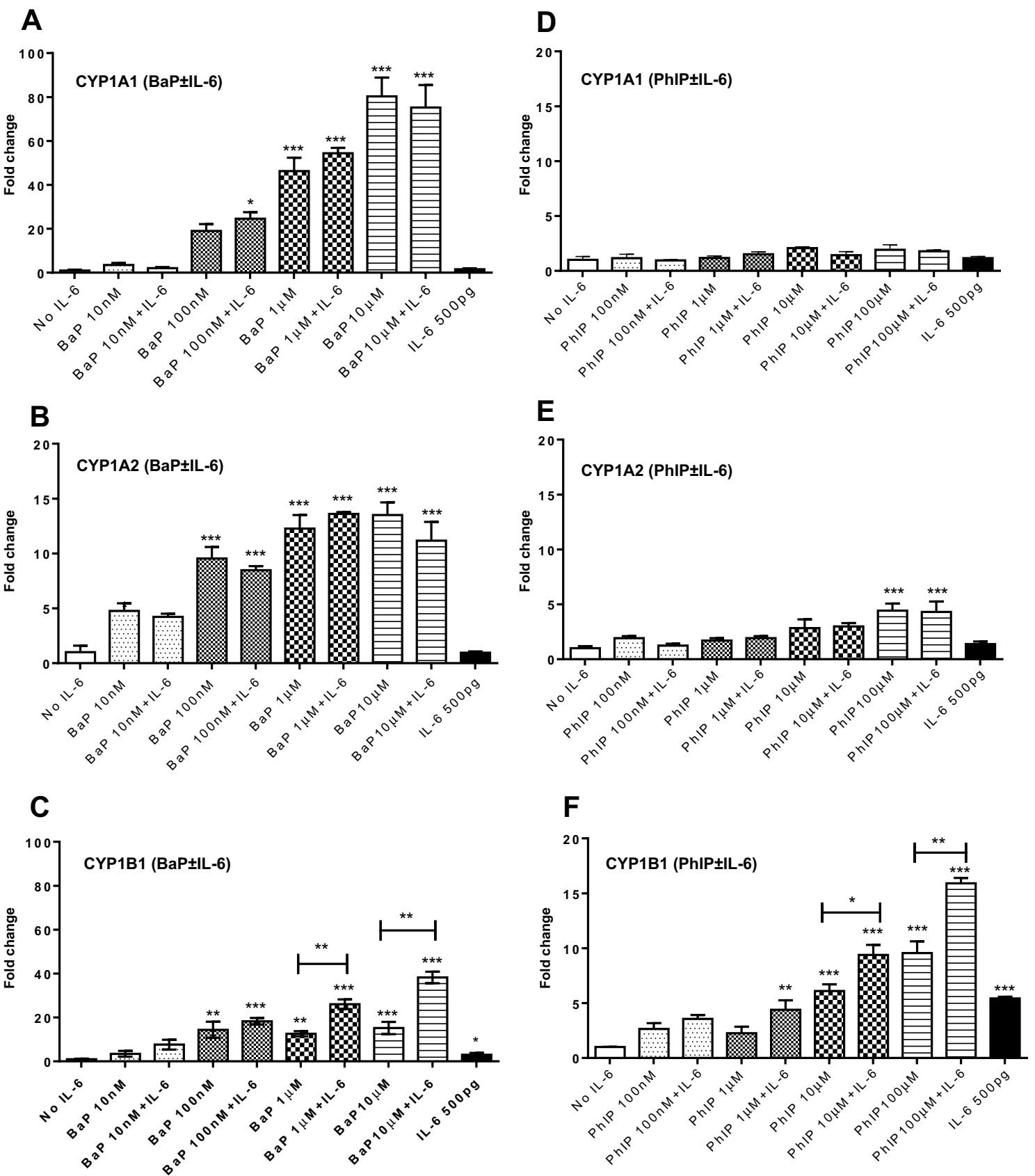

Fig. 2 Effect of IL-6 on the induction of CYP1 enzymes by BaP and $\mathrm{PhIP}$ in MCF-7 cells. CYP1A1 CYP1A2, CYP1B1 induction by BaP $(\mathbf{a}, \mathbf{b}, \mathbf{c})$ and $\mathrm{PhIP}(\mathbf{d}, \mathbf{e}, \mathbf{f})$ expression were measured by RT-qPCR. Data were normalized to expression of GAPDH and are shown relative to control $0.1 \%$ DMSO and $0.1 \%$ albumin in PBS (No IL-6). Sta-

in the lung, and Dreij K et al. previously showed that BaP stimulates the production of inflammatory cytokines (IL-6, IL-8) in normal human lung fibroblasts (Dreij et al. 2010), however, we are not aware of any report that links PAHs with the production of cytokines in breast cancer or any mammary cell line. We therefore investigated whether $\mathrm{BaP}$ induces IL-6 in mammary cells. In this context, it is tistically significant differences compared to no IL-6 and PhIP/BaP alone were calculated using one-way ANOVA with a Dunnett's posttest (GraphPad Prism 5, *** $p<0.001, * * p<0.01, * p<0.05$ ). Error bars represent the SEM for independent cultures $(n=3)$

noteworthy that the MDA-MB-231 cell line is reported to constitutively express IL-6 (Chiu et al. 1996). We found that there was no change in IL-6 expression in MDAMB-231 cells treated with $\mathrm{BaP}$ for $24 \mathrm{~h}$, but a significant increase in IL-6 expression was seen in a dose-dependent manner following $6 \mathrm{~h} \mathrm{BaP}$ treatment of cells (Fig. 7e) which is line with the previous reports that IL-6 induction 

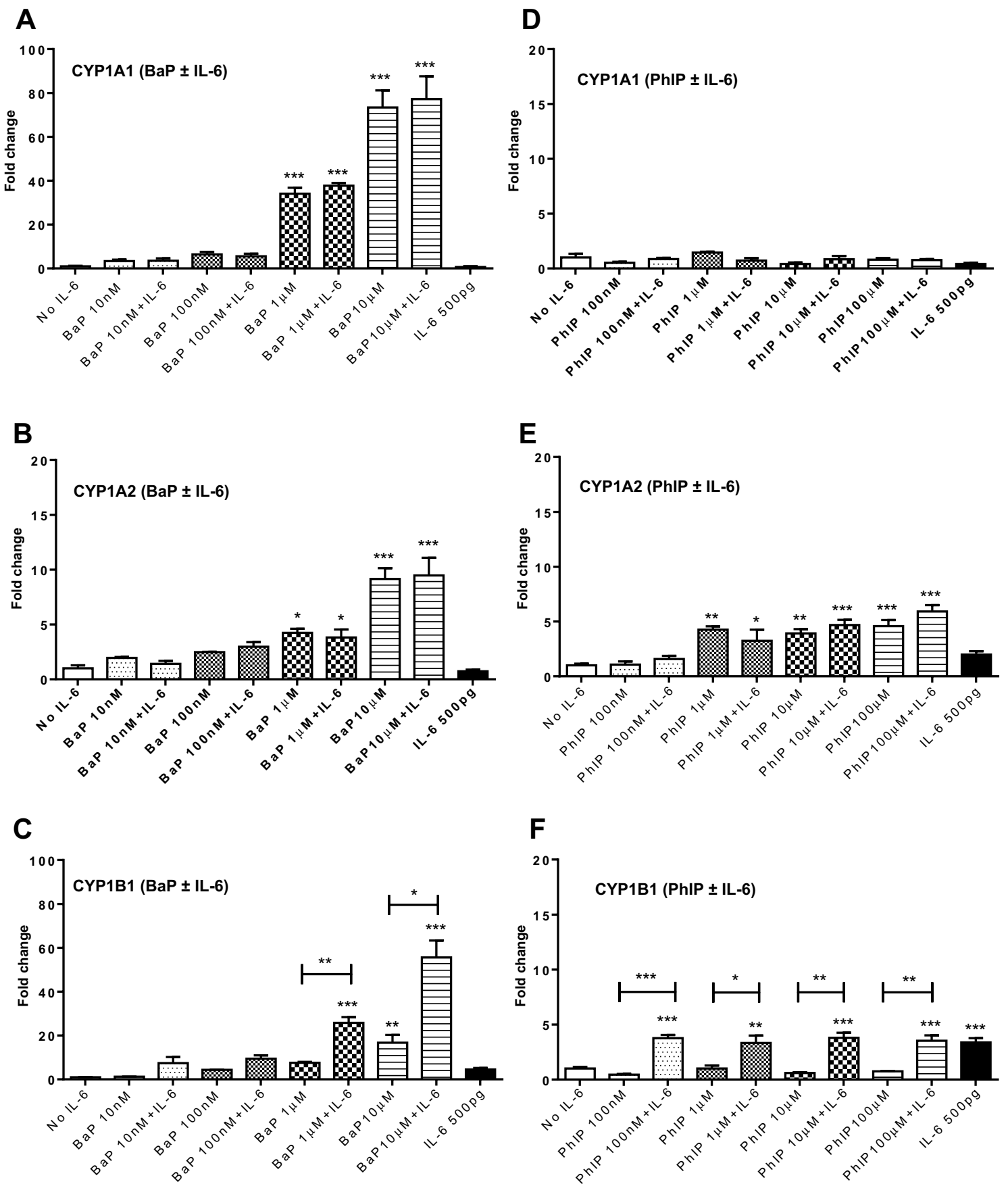

Fig. 3 Effect of IL-6 (500 pg/ml) on the induction of CYP1 enzymes by $\mathrm{BaP}$ and $\mathrm{PhIP}$ in MDA-MB-231 cells. CYP1A1, CYP1A2, CYP1B1 induction by $\mathrm{BaP}(\mathbf{a}, \mathbf{b}, \mathbf{c})$ and $\mathrm{PhIP}(\mathbf{d}, \mathbf{e}, \mathbf{f})$ expression were measured by RT-qPCR. Data were normalized to expression of GAPDH and are shown relative to control 0.1\% DMSO and

$0.1 \%$ albumin in PBS (No IL-6). Statistically significant differences between IL- 6 and $\mathrm{BaP} / \mathrm{PhIP}$ alone were calculated using one-way ANOVA with a Dunnett's post-test (GraphPad Prism 5, ***p $<0.001$, $* * p<0.01, * p<0.05)$. Error bars represent the SEM for independent cultures $(n=3)$

showed rapid kinetics (Gan et al. 1991). We therefore examined whether BaP-driven miR27b and IL-6 mRNA expression were associated and found a negative correlation ( $p<0.0001$, Pearson's product moment correlation),

suggesting $\mathrm{BaP}$ alone can enhance the inflammatory environment by up-regulating IL-6 gene expression in cells constitutively expressing this gene (MDA-MB-231), leading to reduction in miR27b expression. 
A
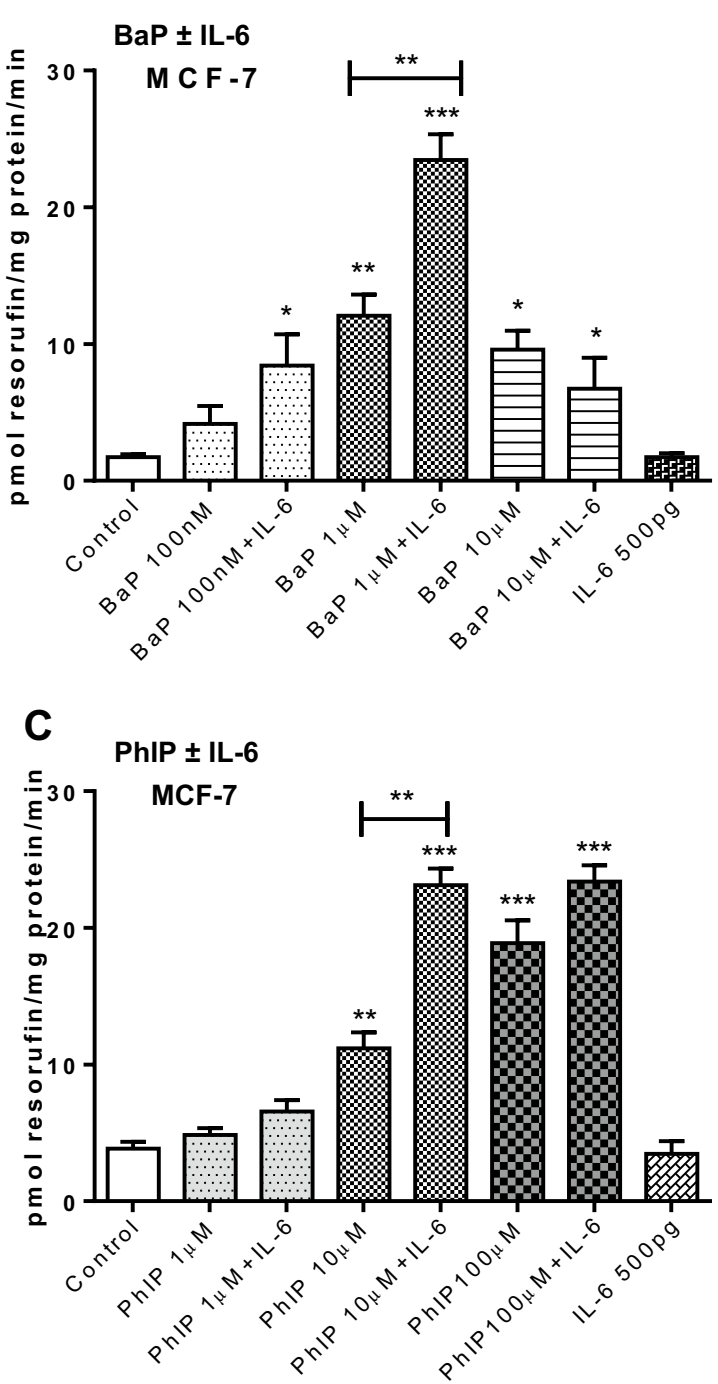

Fig. 4 EROD activity induced by pro-carcinogens in the presence of IL-6 (500 pg/ml): Treatment with $\mathrm{BaP}(\mathbf{a}, \mathbf{b})$ and $\mathrm{PhIP}(\mathbf{c}, \mathbf{d})$ in the presence or absence of IL-6 in MCF-7 (a, c) and MDA-MB-231 (b, d) cells. Statistically significant differences between carcinogen treated vs. IL6 co-treated samples were calculated by Student's $t$

\section{miR27b and CYP1B1 expression}

To further confirm if miR27b can regulate CYP1B1 expression, cells were transfected with miR27b inhibitor. Both MCF-7 and MDA-MB-231 cells express endogenous low levels of miR27b, we therefore used a chemically modified antisense oligonucleotide miRNA inhibitor designed to bind and sequester the complimentary mature microRNA strand (Stenvang et al. 2012). MCF-7 and MDA-MB-231 cells were transfected with scrambled oligonucleotide or miR27b inhibitor using LIPO2000 for up to $72 \mathrm{~h}$ (Dalby et al. 2004). Optimal inhibition of miRNA expression was determined to be $24 \mathrm{~h}$ for MCF-7 cells and $48 \mathrm{~h}$ for MDA-MB-231 cells.
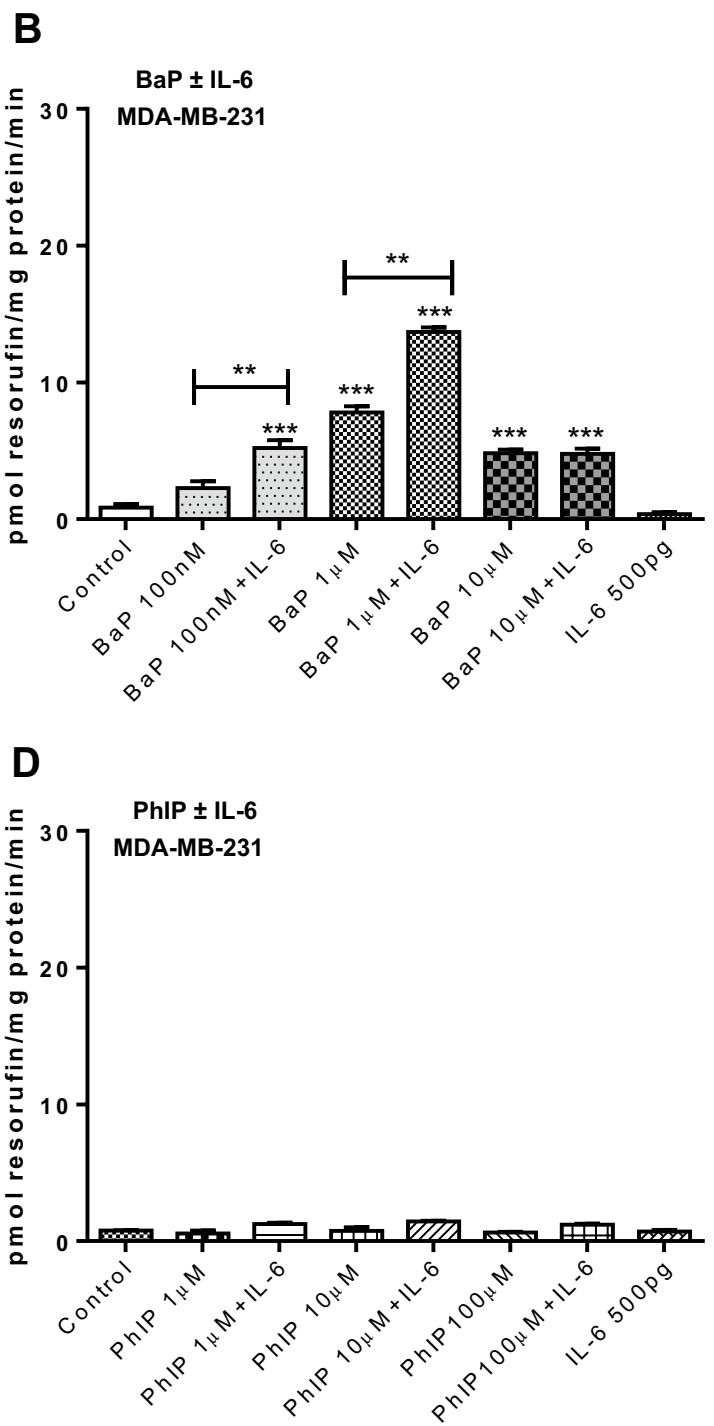

test and between control (no IL-6, 0.1\% DMSO 0.1\% albumin) and treated samples using one-way ANOVA with a Dunnett's post-test in GraphPad Prism 5 (GraphPad Prism 5, *** $p<0.001$, ** $p<0.01$, $* p<0.05)$. Error bars represent the SEM for independent cultures $(n=3)$

Measurement of miRNA levels indicated miR27b was decreased significantly in both cell lines transfected with mir27b inhibitor (Fig. 8a and c). Importantly, significant reduction of miR27b expression was accompanied with a significant increase in CYP1B1 expression (Fig. 8b and d), supporting the proposal that miR27b is involved in the regulation of CYP1B1 in these mammary cell lines. 
Table 2 Cytotoxicity and micronucleus frequency following $24 \mathrm{~h}$ treatment with different doses of $\mathrm{BaP}$ and $\mathrm{PhIP}$ in mammary cancer cell lines

\begin{tabular}{|c|c|c|c|c|}
\hline \multirow[t]{2}{*}{ Treatments } & \multicolumn{2}{|l|}{ MCF-7 } & \multicolumn{2}{|l|}{ MDA-MB-231 } \\
\hline & Cytotoxicity $^{\mathrm{a}}$ & Micronuclei $^{\mathrm{b}}$ & Cytotoxicity $^{\mathrm{a}}$ & Micronuclei $^{\mathrm{b}}$ \\
\hline Control & $90.0 \pm 2.7$ & $3.2 \pm 0.8$ & $88.3 \pm 1.2$ & $7 \pm 0.9$ \\
\hline $\mathrm{BaP} 10 \mathrm{nM}$ & $90.1 \pm 2.3$ & $9.7 \pm 2.5$ & $87.3 \pm 1.7$ & $37.8 \pm 10$ \\
\hline $\mathrm{BaP} 100 \mathrm{nM}$ & $87.2 \pm 3.9$ & $16 \pm 1.9$ & $87.3 \pm 2.3$ & $40.3 \pm 12.3$ \\
\hline $\mathrm{BaP} 1 \mu \mathrm{M}$ & $85.9 \pm 2.3$ & $29.7 \pm 4.5$ & $86.1 \pm 4.9$ & $65.2 \pm 9.6$ \\
\hline $\mathrm{BaP} 10 \mu \mathrm{M}$ & $83.5 \pm 1.0$ & $49.8 \pm 11.9$ & $82.4 \pm 0.7$ & $114.7 \pm 8.9$ \\
\hline Etoposide & $81.7 \pm 1.4$ & $124.3 \pm 28.7$ & $83.6 \pm 2.6$ & $321.7 \pm 51.1$ \\
\hline Control & $89.0 \pm 1.0$ & $3.5 \pm 0.5$ & $89 \pm 7.2$ & $3.5 \pm 1.0$ \\
\hline PhIP100 nM & $86.0 \pm 2.4$ & $12.8 \pm 5.1$ & $87.2 \pm 0.9$ & $3.2 \pm 2.5$ \\
\hline PhIP1 $\mu \mathrm{M}$ & $85.6 \pm 2.4$ & $22.3 \pm 2.6$ & $88.1 \pm 0.9$ & $4.7 \pm 1.8$ \\
\hline PhIP10 $\mu \mathrm{M}$ & $85.8 \pm 2.6$ & $29.2 \pm 3.4$ & $90.4 \pm 4.3$ & $9.0 \pm 0.9$ \\
\hline PhIP100 $\mu \mathrm{M}$ & $82.7 \pm 1.7$ & $49 \pm 3.5$ & $87.7 \pm 1.5$ & $13.7 \pm 1.3$ \\
\hline Etoposide & $81.7 \pm 1.4$ & $172 \pm 4.8$ & $83.7 \pm 2.2$ & $121.0 \pm 27.7$ \\
\hline
\end{tabular}

Values are mean \pm SEM, for three independent cultures

${ }^{a}$ Cytotoxicity is expressed as a \% viable cells

${ }^{\mathrm{b}}$ Micronuclei frequency per 1000 cells
A

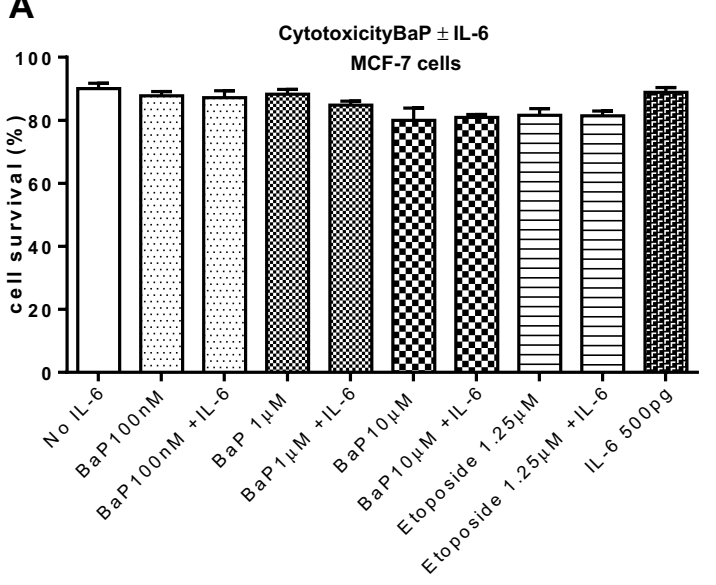

C

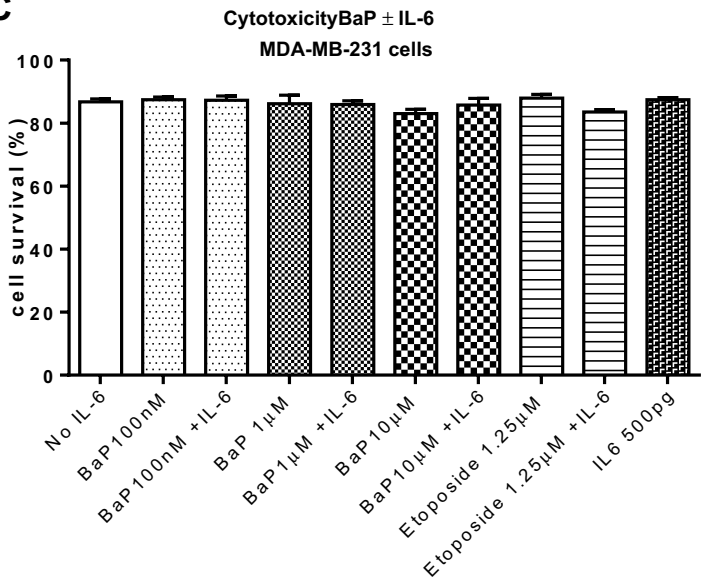

Fig. 5 Cytotoxicity of carcinogens in the presence of IL-6 (500 pg/ $\mathrm{ml})$ in breast cells, in MCF-7 (a, b) and MDA-MB-231 (c, d) cells treated with $\mathrm{BaP}$ or PhIP in the presence or absence of IL-6 for $24 \mathrm{~h}$.

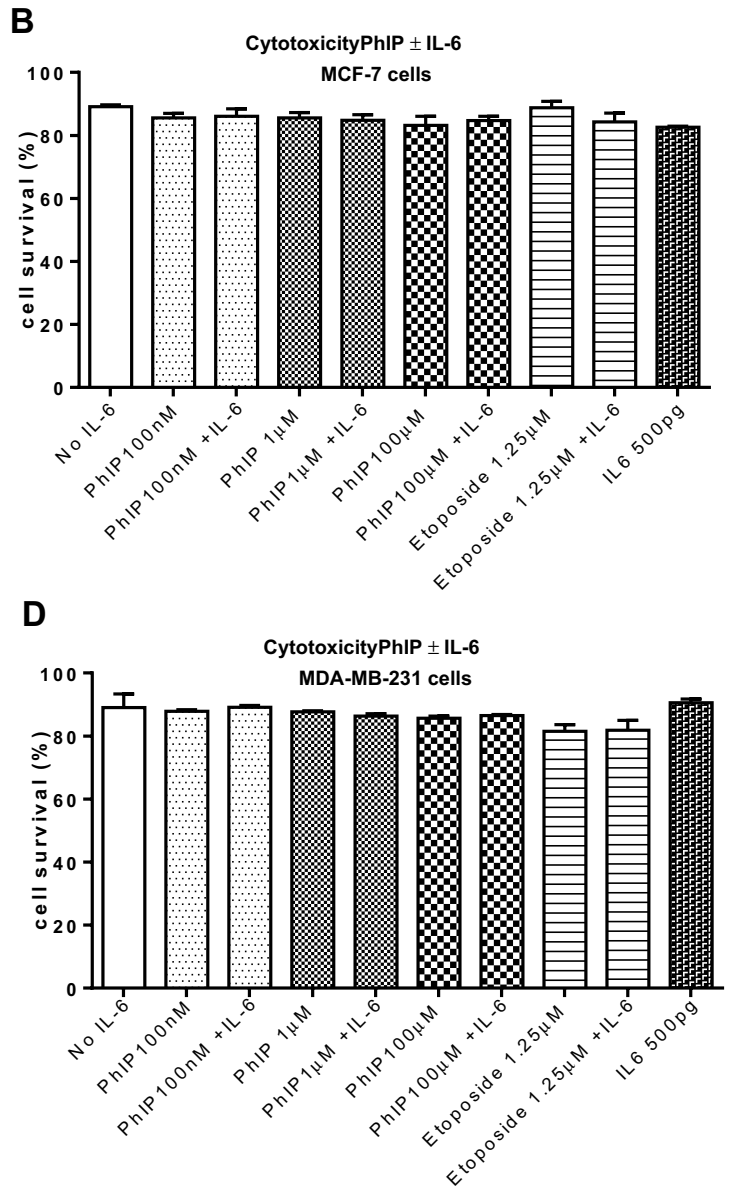

Cells were harvested $48 \mathrm{~h}$ post-treatment. Cytotoxicity was measured by cell counting using haemocytometer and is expressed as \% of cell survival. No significant change in cell survival was observed 
A

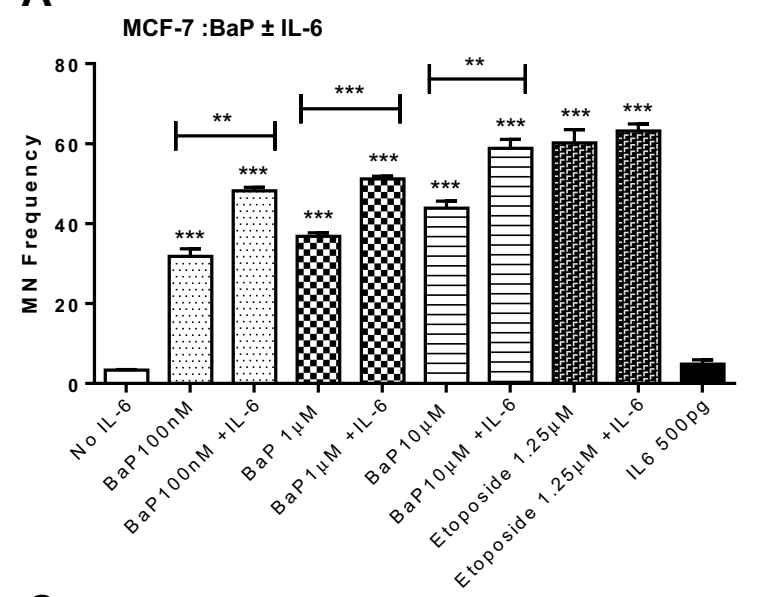

C

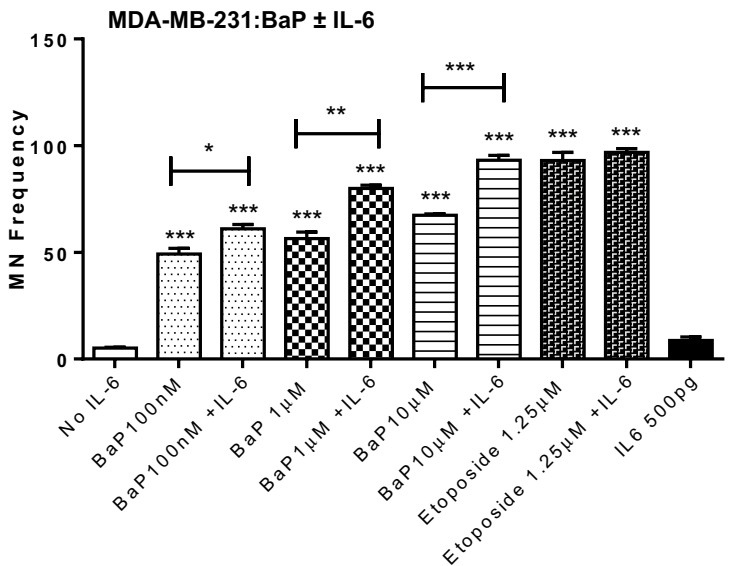

Fig. 6 Genotoxicity of $\mathrm{BaP} / \mathrm{PhIP}$ in the presence of IL-6 in breast cells: by $\mathrm{BaP}(\mathbf{a}, \mathbf{c})$ and $\mathrm{PhIP}(\mathbf{b}, \mathbf{d})$ in presence or absence of IL-6 in MCF-7 (a, b) and MDA-MB-231 (c, d) cells. Etoposide $(1.25 \mu \mathrm{M})$ was used as a positive control. Micronuclei (MN) frequency per 1000 cells was determined following treatment (1000 cells/slide; two slides per culture). Statistically significant differences between carcino-

\section{Discussion}

In breast cancer, elevated circulating levels of pro-inflammatory cytokine IL6 have been linked with poor prognosis (Zhang and Adachi 1999; Fouad et al. 2014), and consumption of a pro-inflammatory diet is also associated with an increased incidence of breast cancer (Shivappa et al. 2015). These results suggest that IL- 6 can drive carcinogenesis leading to breast cancer and dietary induction of IL-6 can contribute to this, but the underlying mechanism remains unclear. Here using established mammary chemical carcinogens, we propose that IL- 6 can enhance the activation of dietary carcinogens leading to genetic damage in mammary cells as summarized in Fig. 9.

The current study presents mechanistic evidence that at levels reported to be circulating in clinical cancer (Blay et al. 1992; Bachelot et al. 2003; Goswami et al. 2013; Brouwers
B
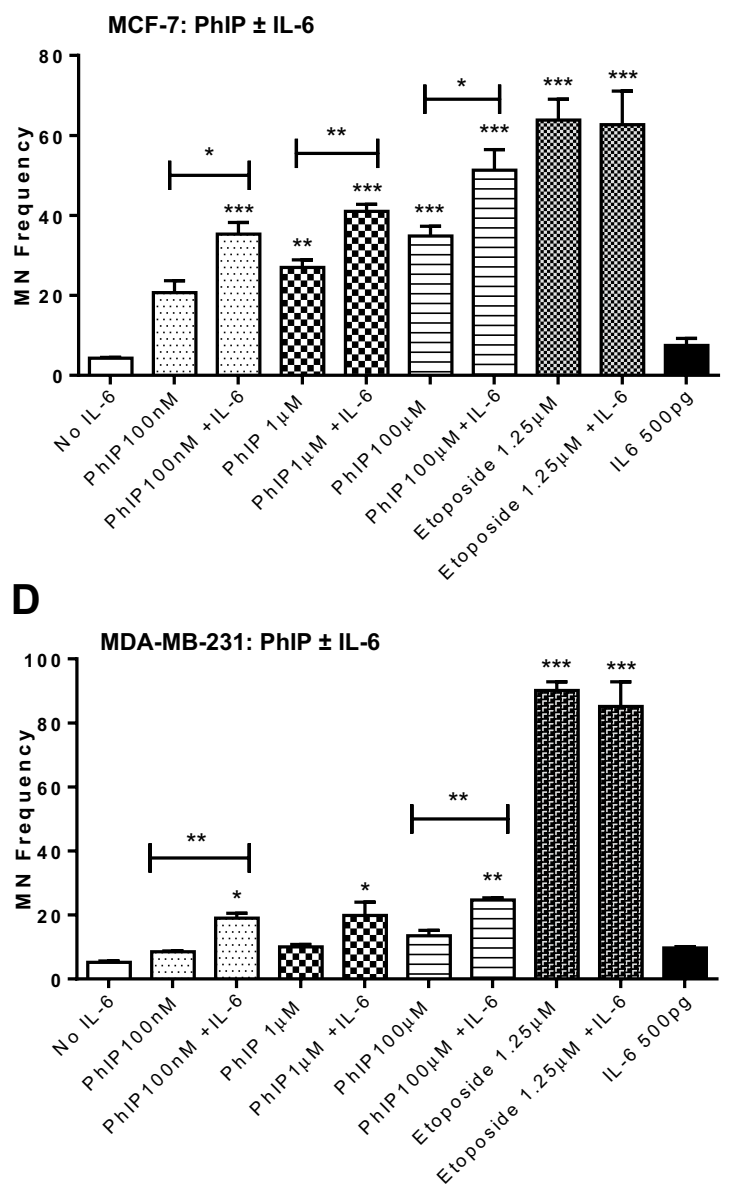

gen treated vs. IL6 co-treated samples were calculated by Student's $t$ test and between control (no IL- $6=0.1 \%$ DMSO $0.1 \%$ albumin) and treated samples using one-way ANOVA with a Dunnett's post-test in GraphPad Prism 5. *** $p<0.001, * * p<0.01, * p<0.05$. Error bars represent the SEM for independent cultures $(n=3)$

et al. 2015) and present in breast tumors (Ueno et al. 2000; Knupfer et al. 2004; Knupfer and Preiss 2007), IL-6 affects the metabolic competency of mammary cells leading to an increase in the genotoxicity of CYP-activated chemical carcinogens such as $\mathrm{BaP}$ and $\mathrm{PhIP}$. Both compounds are procarcinogens present in smoke and cooked food that require metabolic activation to exert their genotoxicity (Winton et al. 1990; Brooks et al. 1994, 1999; Gooderham et al. 1996, 1997, 2002; Yadollahi-Farsani et al. 1996). To the best of our knowledge, this is the first report to show the effect of interleukins on the genotoxicity of dietary carcinogens in mammary cell lines, although, TNF- $\alpha$ (pro-inflammatory cytokine) was shown to increase the genotoxicity of $\mathrm{BaP}$ in alveolar epithelial type II cells (Umannova et al. 2008) and IL-8 has been shown to increase BaP metabolism in human lung epithelial cells (Shi et al. 2017). Recently, our laboratory has reported that IL-6 can increase the genotoxicity of 
A

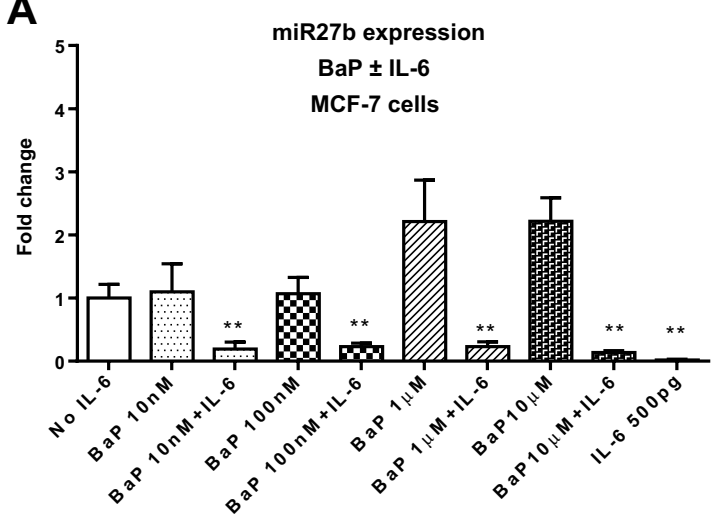

C

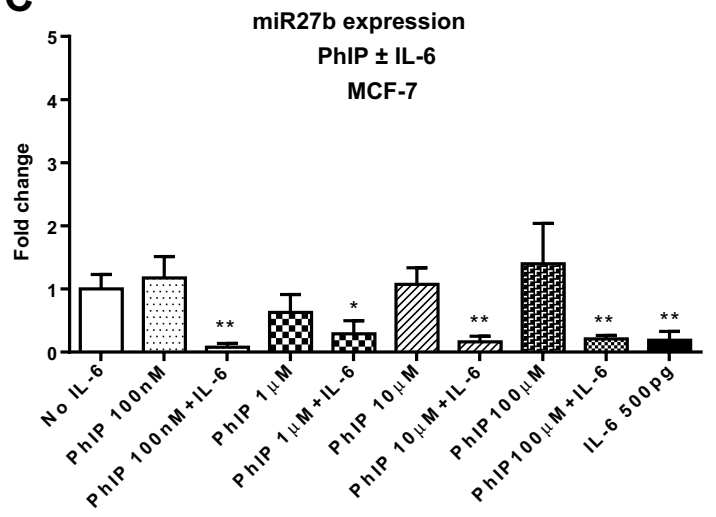

B
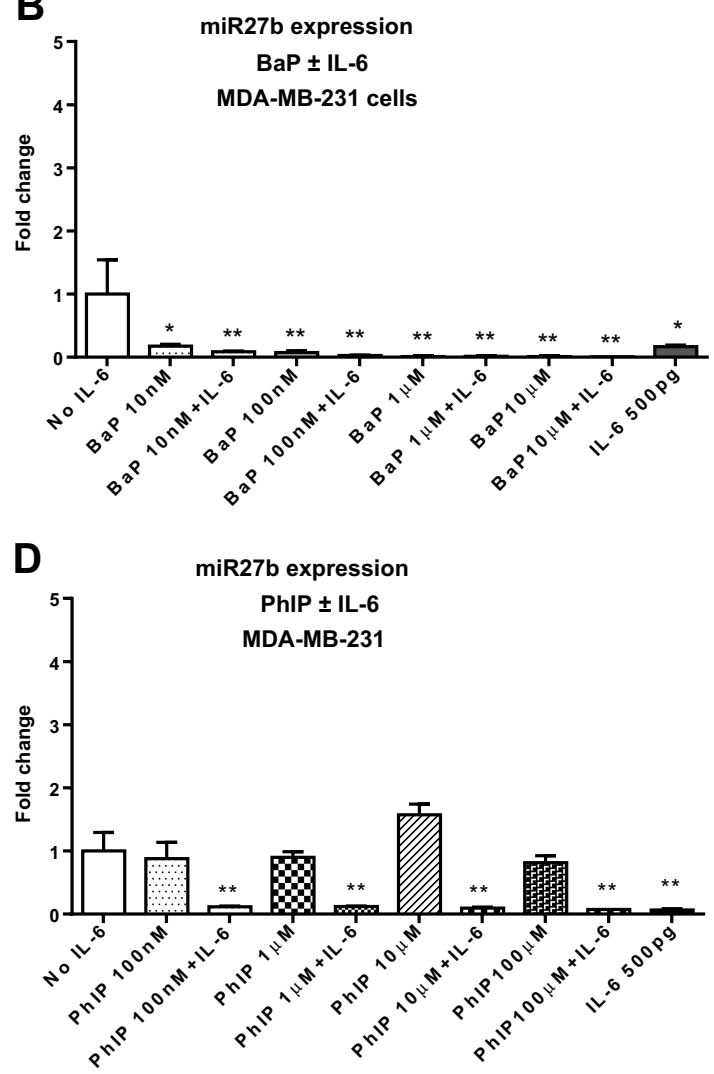

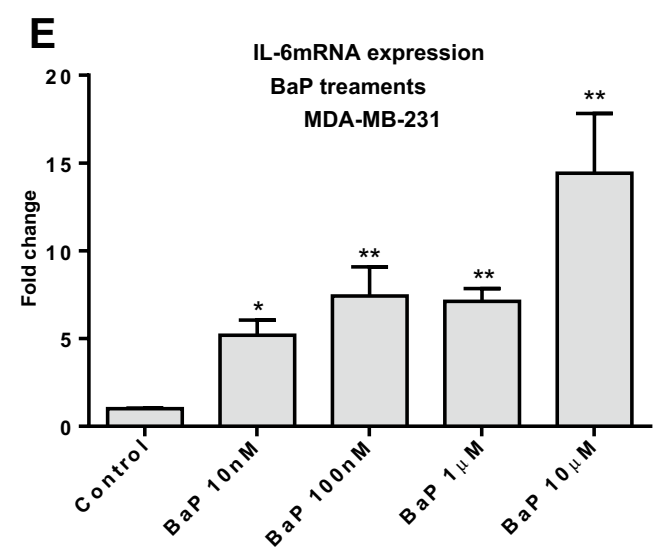

Fig. 7 Expression of $\mathrm{miR} 27 \mathrm{~b}$ by $\mathrm{BaP}$ and $\mathrm{PhIP}$ in presence or absence of IL-6 in MCF-7 (a, c) and MDA-MB-231 cells (b, d): miRNA27b was measured by RT-qPCR. Data were normalized to expression of U6 and is shown relative to control 0.1\% DMSO and $0.1 \%$ albumin (No IL-6). e: IL-6 gene expression after $6 \mathrm{~h} \mathrm{BaP}$ treatment. Significant differences were calculated using one-way ANOVA with a Dunnett's post-test (GraphPad Prism 5, *** $p<0.001$, $\left.{ }^{* *} p<0.01, * p<0.05\right)$ and are shown for comparisons between control vs treated samples. Error bars represent SEM for independent cultures $(n=3)$
$\mathrm{BaP} / \mathrm{PhIP}$ by regulation of CYP1B1 expression in colorectal cells (Patel and Gooderham 2015a, b).

Extending this finding to mammary cells, we here show that IL-6 can induce CYP1B1 via a miR27b mechanism leading to increased bio-activation of $\mathrm{BaP} / \mathrm{PhIP}$ and that this has genotoxic consequences in two different mammary cell lines. IL- 6 treatment failed to change the level of CYP1A1 or CYP1A2 expression and activity, but it did increase CYP1B1 gene expression. Previously it was generally accepted that under conditions of inflammation or infection, hepatic CYP enzyme activity tended to be depressed (Deloria et al. 1985; Gooderham and Mannering 1986; Morgan 1989; Renton 2004; Aitken et al. 2006). Consistent with this, IL-6 represses the inducible expression of CYP1As 
A

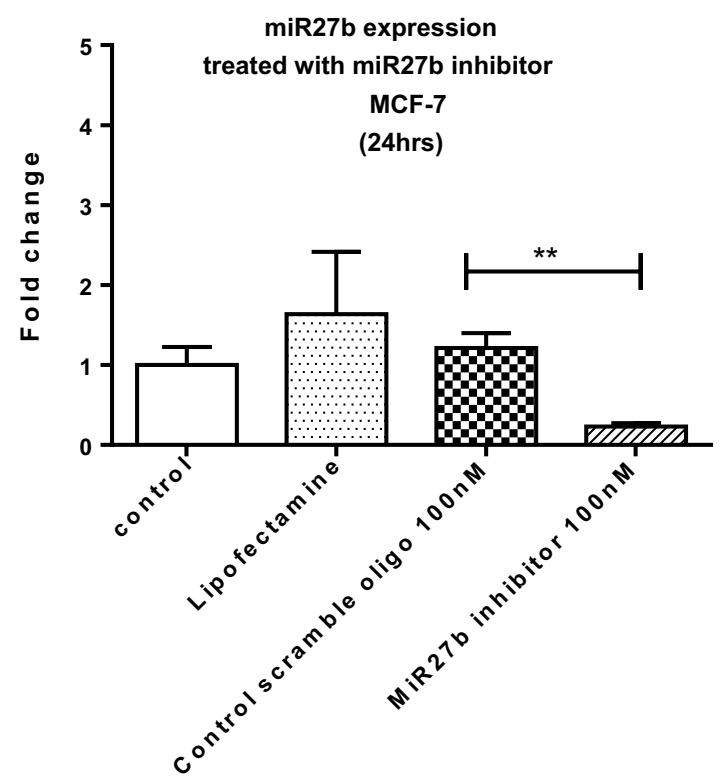

C

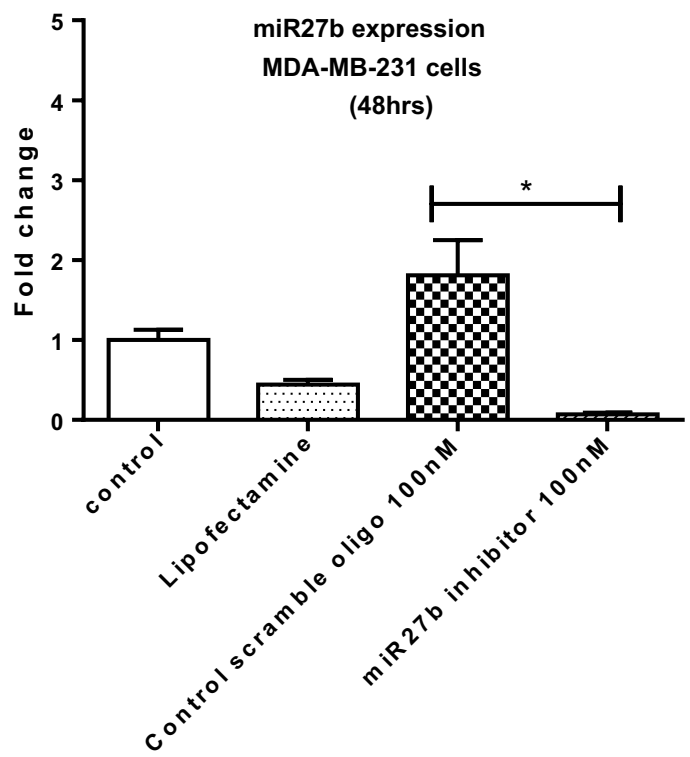

Fig. $8 \mathrm{MiR} 27 \mathrm{~b}$ and CYP1B1 gene expression after transfection with miR27b inhibitor; miR27b expression in MCF-7 (a) and MDAMB-231 (c), CYP1B1 mRNA expression in MCF-7 (b) and MDAMB-231 (d) after transfection with miR27b inhibitor $(25 \mu \mathrm{M})$ for $24 \mathrm{~h}$ in MCF-7 cells and $48 \mathrm{~h}$ in MDA-MB-231 cells. Statistically

and CYP3A4 in human hepatocytes (Muntane-Relat et al. 1995) and IL-6 plasma levels are inversely related to hepatic CYP1A2 and CYP2E1 expression in cardiac arrest patients (Frye et al. 2002). Down-regulation of CYP1A2 and CYP2E1 is IL-6 mediated in mouse hepatocytes (Siewert
B
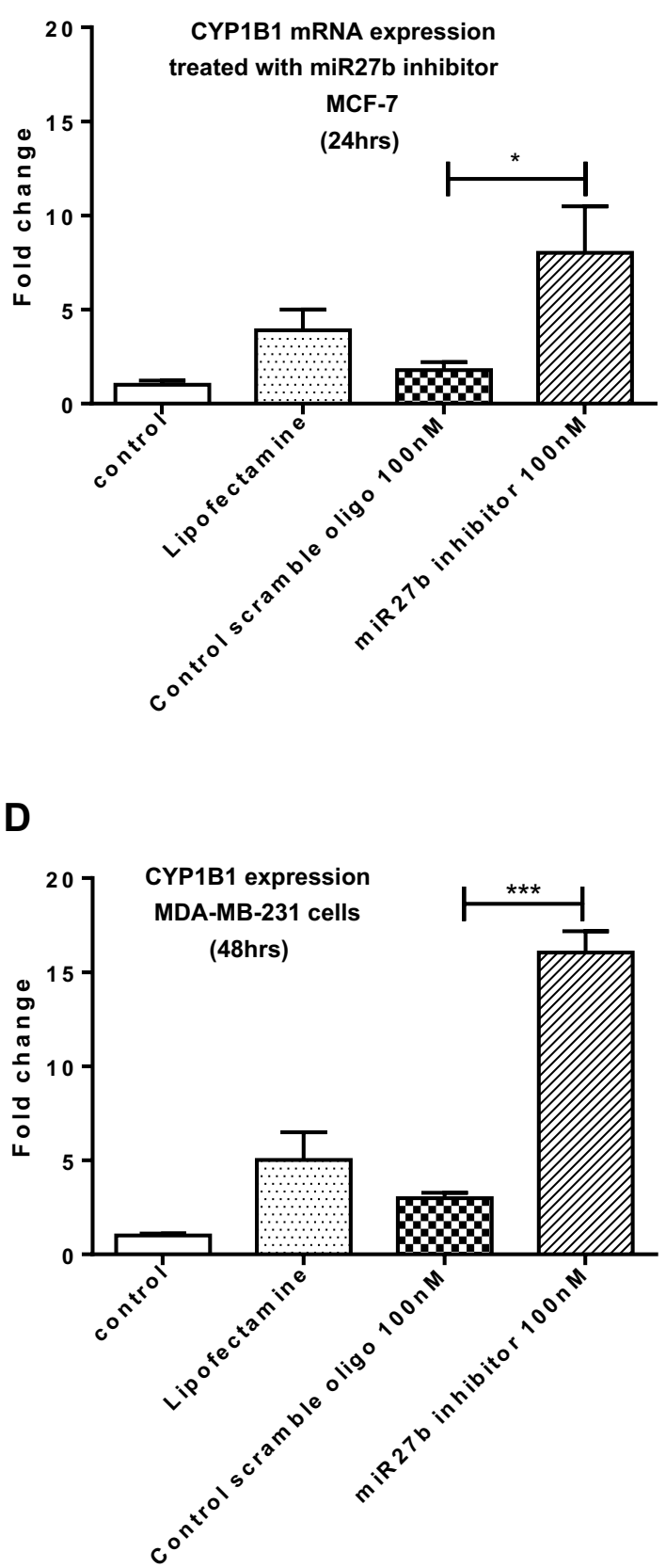

significant differences were calculated using Student's $t$ test (GraphPad Prism 5) control scramble oligo vs treated miR27b inhibitor. $(* * * p<0.001, * * p<0.01, * p<0.05)$. Error bars represent SEM for independent cultures $(n=3)$

et al. 2000) and IL-1 $\beta$, IL-6, tumor necrosis factor-alpha and interferon-gamma reduce CYP1A1, 1A2 and 3A6 expression in rabbit hepatocytes (Bleau et al. 2003). Importantly, each of these studies has examined hepatic drug metabolism activity, whereas the current study used mammary cells. 
Fig. 9 Proposed mechanism of IL-6-mediated genotoxicity of BaP and PhIP: IL-6 induces CYP1B1 independently of Aryl hydrocarbon receptor (AhR) via down-regulation of miR27b. $\mathrm{BaP}$ also induces expression of IL-6. Induction of CYP1B1 resulted in increased bio-activation of food-derived carcinogens $\mathrm{BaP}$ and PhIP, leading to induction of genotoxicity

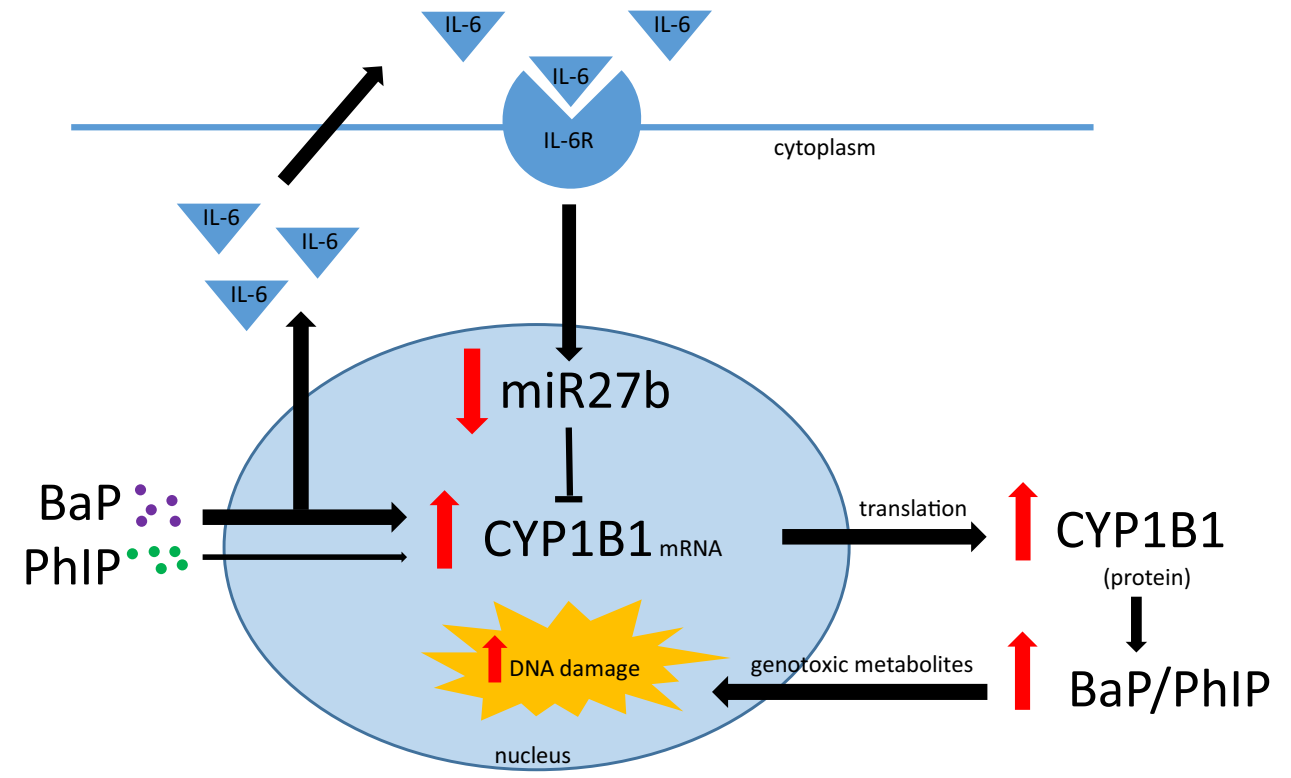

These observations along with the current work and that previously reported (Patel et al. 2014; Patel and Gooderham $2015 \mathrm{a}, \mathrm{b})$ suggest that systemic inflammation elicits tissuespecific effects on xenobiotic metabolism.

The selective induction of CYP1B1 metabolic competency in mammary cells exposed to clinically relevant concentrations of IL-6 has potentially important clinical significance. Our data show that under such conditions, mammary cells exposed to IL-6 acquire increased metabolic competency to activate dietary/environmental carcinogens such as $\mathrm{BaP} / \mathrm{PhIP}$ promoting genotoxic/mutagenic events. In this context, a number of clinical studies in different populations have linked high CYP1B1 expression with an increase in the risk of breast cancer (Gaudet et al. 2006; Jiao et al. 2010; Blackburn et al. 2015). In addition to a role in xenobiotic carcinogen activation, it is known that CYP1B1 catalyzes the conversion of $17-\beta$-estradiol to catechol estrogen metabolites that promote the invasiveness of ER responsive breast cancer (Gaudet et al. 2006; Jiao et al. 2010; Blackburn et al. 2015). Furthermore, BaP and PhIP are present in cigarette smoke (Manabe et al. 1991; Pfeifer et al. 2002) and active smoking is linked with increased incidence of ER positive mammary cancers (Kawai et al. 2014). This is consistent with results from this study and previous studies from our laboratory (Lauber et al. 2004; Lauber and Gooderham 2007, 2011; Patel et al. 2014; Malik et al. 2018a, b), which report the estrogenicity of $\mathrm{BaP}$ and $\mathrm{PhIP}$ in addition to their well-documented metabolically mediated DNA-damaging properties.

This study and previous reports propose that IL- 6 can influence miR7b expression to regulate the expression of CYP1B1, which coincidently is highly expressed in breast cancer (Gaudet et al. 2006; Jiao et al. 2010; Blackburn et al.
2015). Overexpression of CYP1B1 is not only linked with increased risk of breast cancer but also shown to decrease the sensitivity of certain anti-cancer drugs (e.g., docetaxel, flutamide) leading to poor prognosis (Rodriguez-Antona and Ingelman-Sundberg 2006). Therefore, CYP1B1 is considered an attractive therapeutic target in breast cancer (McFadyen et al. 2004; Safe et al. 2013). In this study, we have confirmed that miR27b has the potential to selectively target CYP1B1 expression in mammary cells, and thus manipulation of miR27b activity could potentially play a role in attenuating key DNA damage in cancer.

Another important finding of the present study was elevation of IL- 6 following BaP treatment of the mammary epithelial cells, suggesting that this dietary carcinogen is itself capable of inducing inflammation. This we reported in a previous paper that described the potential of $\mathrm{BaP}$ to upregulate inflammation within the microenvironment to influence cell migration and invasion (Malik et al. 2018a, b). Consistent with this, others have shown that BaP stimulates the production of inflammatory cytokines (IL-6, IL-8) in normal human lung fibroblasts (Dreij et al. 2010). Thus, we have established a cyclical mechanism where exposure to a human carcinogen promotes inflammation that in turn can induce metabolic activation of the carcinogen leading to genotoxic consequences (Fig. 9) and thereby carcinogenesis.

The consumption of meat has been associated with the development of cancer including breast cancer. Interestingly, a prospective study showed that consumption of red meat can result in elevated levels of inflammatory biomarkers in women (Ley et al. 2014) and pro-inflammatory diet intake can increase the incidence of breast cancer (Shivappa et al. 2015). Epidemiological studies suggests that risk of cancer in people consuming red meat, particularly processed meat, 
is higher compared to non-eaters (Sinha and Rothman 1999; Wu et al. 2009).

These epidemiological studies all support an association between meat intake, inflammation and cancer. Here we have reported a mechanistic explanation for these trilateral associations showing the influence of inflammation on the metabolic activation of food-derived genotoxins by CYPs and the potential genotoxic consequences of these events.

Acknowledgements We thank the Government of Pakistan for the award of a scholarship to D. Malik.

Funding This study is funded by Higher Education Commission, Pakistan.

\section{Compliance with ethical standards}

Conflict of interest All authors declare that they have no actual or potential conflicts of interest.

Open Access This article is distributed under the terms of the Creative Commons Attribution 4.0 International License (http://creativeco mmons.org/licenses/by/4.0/), which permits unrestricted use, distribution, and reproduction in any medium, provided you give appropriate credit to the original author(s) and the source, provide a link to the Creative Commons license, and indicate if changes were made.

\section{References}

Aitken AE, Richardson TA, Morgan ET (2006) Regulation of drugmetabolizing enzymes and transporters in inflammation. Annu Rev Pharmacol Toxicol 46:123-149

Anand P, Kunnumakara AB, Sundaram C, Harikumar KB, Tharakan ST, Lai OS, Sung B, Aggarwal BB (2008) Cancer is a preventable disease that requires major lifestyle changes. Pharm Res 25(9):2097-2116

Bachelot T, Ray-Coquard I, Menetrier-Caux C, Rastkha M, Duc A, Blay JY (2003) Prognostic value of serum levels of interleukin 6 and of serum and plasma levels of vascular endothelial growth factor in hormone-refractory metastatic breast cancer patients. $\mathrm{Br}$ J Cancer 88(11):1721-1726

Bachour T, Bennett K (2011) The role of MicroRNAs in breast cancer. J Assoc Genet Technol 37(1):21-28

Barrett JH, Smith G, Waxman R, Gooderham N, Lightfoot T, Garner RC, Augustsson K, Wolf CR, Bishop DT, D. Forman and G. Colorectal Cancer Study (2003) Investigation of interaction between $\mathrm{N}$-acetyltransferase 2 and heterocyclic amines as potential risk factors for colorectal cancer. Carcinogenesis 24(2):275-282

Blackburn HL, Ellsworth DL, Shriver CD, Ellsworth RE (2015) Role of cytochrome $\mathrm{P} 450$ genes in breast cancer etiology and treatment: effects on estrogen biosynthesis, metabolism, and response to endocrine therapy. Cancer Causes Control 26(3):319-332

Blay JY, Negrier S, Combaret V, Attali S, Goillot E, Merrouche Y, Mercatello A, Ravault A, Tourani JM, Moskovtchenko JF et al (1992) Serum level of interleukin 6 as a prognosis factor in metastatic renal cell carcinoma. Cancer Res 52(12):3317-3322

Bleau AM, Maurel P, Pichette V, Leblond F, du Souich P (2003) Interleukin-1beta, interleukin-6, tumour necrosis factor-alpha and interferon-gamma released by a viral infection and an aseptic inflammation reduce CYP1A1, 1A2 and 3A6 expression in rabbit hepatocytes. Eur J Pharmacol 473(2-3):197-206

Boobis AR, Lynch AM, Murray S, de la Torre R, Solans A, Farre M, Segura J, Gooderham NJ, Davies DS (1994) CYP1A2-catalyzed conversion of dietary heterocyclic amines to their proximate carcinogens is their major route of metabolism in humans. Cancer Res 54(1):89-94

Bray F, McCarron P, Parkin DM (2004) The changing global patterns of female breast cancer incidence and mortality. Breast Cancer Res 6(6):229-239

Brooks RA, Gooderham NJ, Zhao K, Edwards RJ, Howard LA, Boobis AR, Winton DJ (1994) 2-Amino-1-methyl6-phenylimidazo[4,5-b]pyridine is a potent mutagen in the mouse small intestine. Cancer Res 54(7):1665-1671

Brooks RA, Gooderham NJ, Edwards RJ, Boobis AR, Winton DJ (1999) The mutagenicity of benzo[a]pyrene in mouse small intestine. Carcinogenesis 20(1):109-114

Brouwers B, Dalmasso B, Hatse S, Laenen A, Kenis C, Swerts E, Neven P, Smeets A, Schoffski P, Wildiers H (2015) Biological ageing and frailty markers in breast cancer patients. Aging (Albany NY) 7(5):319-333

Chiu JJ, Sgagias MK, Cowan KH (1996) Interleukin 6 acts as a paracrine growth factor in human mammary carcinoma cell lines. Clin Cancer Res 2(1):215-221

Crespi CL, Penman BW, Steimel DT, Smith T, Yang CS, Sutter TR (1997) Development of a human lymphoblastoid cell line constitutively expressing human CYP1B1 cDNA: substrate specificity with model substrates and promutagens. Mutagenesis 12(2):83-89

Dalby B, Cates S, Harris A, Ohki EC, Tilkins ML, Price PJ, Ciccarone VC (2004) Advanced transfection with Lipofectamine 2000 reagent: primary neurons, siRNA, and high-throughput applications. Methods 33(2):95-103

Davis HJ (1968) Gas chromatographic determination of benzo(a)pyrene in cigarette smoke. Anal Chem 40(10):1583-1585

Deloria L, Abbott V, Gooderham N, Mannering GJ (1985) Induction of xanthine oxidase and depression of cytochrome P-450 by interferon inducers: genetic difference in the responses of mice. Biochem Biophys Res Commun 131(1):109-114

Deshmukh SK, Srivastava SK, Bhardwaj A, Singh AP, Tyagi N, Marimuthu S, Dyess DL, Dal Zotto V, Carter JE, Singh S (2015) Resistin and interleukin- 6 exhibit racially-disparate expression in breast cancer patients, display molecular association and promote growth and aggressiveness of tumor cells through STAT3 activation. Oncotarget 6(13):11231-11241

Dreij K, Rhrissorrakrai K, Gunsalus KC, Geacintov NE, Scicchitano DA (2010) Benzo[a]pyrene diol epoxide stimulates an inflammatory response in normal human lung fibroblasts through a p53 and JNK mediated pathway. Carcinogenesis 31(6):1149-1157

Felton JS, Knize MK, Turteltaub KW, Buonarati MH, Taylor RT, Vanderlaan M, Watkins BE, Tucker JD, Thompson LH (1991) Mutagens and carcinogens in cooked foods: concentration, potency, and risk. Adv Exp Med Biol 289:133

Fouad TM, Kogawa T, Reuben JM, Ueno NT (2014) The role of inflammation in inflammatory breast cancer. Adv Exp Med Biol 816:53-73

Frye RF, Schneider VM, Fau-Frye CS, Feldman AM (2002) Plasma levels of TNF-alpha and IL-6 are inversely related to cytochrome $\mathrm{P} 450$-dependent drug metabolism in patients with congestive heart failure. J Cardiac Failure 8:315-319 (1071-9164 (Print))

Gan HX, Ruef C, Hall BF, Tobin E, Remold HG, Mellors JW (1991) Interleukin-6 expression in primary macrophages infected with human immunodeficiency virus-1 (HIV-1). AIDS Res Hum Retroviruses 7(8):671-679

Gaudet MM, Chanock S, Lissowska J, Berndt SI, Yang XR, Peplonska B, Brinton LA, Welch R, Yeager M, Bardin-Mikolajczak A, 
Sherman ME, Sutter TR, Garcia-Closas M (2006) Genetic variation of Cytochrome P450 1B1 (CYP1B1) and risk of breast cancer among Polish women. Pharmacogenet Genom 16(8):547-553

Gooderham NJ, Mannering GJ (1986) Depression of cytochrome P-450 and alterations of protein metabolism in mice treated with the interferon inducer polyriboinosinic acid $\mathrm{X}$ polyribocytidylic acid. Arch Biochem Biophys 250(2):418-425

Gooderham NJ, Murray S, Lynch AM, Edwards RJ, Yadollahi-Farsani M, Bratt C, Rich KJ, Zhao K, Murray BP, Bhadresa S, Crosbie SJ, Boobis AR, Davies DS (1996) Heterocyclic amines: evaluation of their role in diet associated human cancer. Br J Clin Pharmacol 42(1):91-98

Gooderham NJ, Murray S, Lynch AM, Yadollahi-Farsani M, Zhao K, Rich K, Boobis AR, Davies DS (1997) Assessing human risk to heterocyclic amines. Mutat Res 376(1-2):53-60

Gooderham NJ, Zhu H, Lauber S, Boyce A, Creton S (2002) Molecular and genetic toxicology of 2-amino-1-methyl-6-phenylimidazo[4,5b]pyridine (PhIP). Mutat Res 506-507:91-99

Gooderham NJ, Creton S, Lauber SN, Zhu H (2007) Mechanisms of action of the carcinogenic heterocyclic amine PhIP. Toxicol Lett 168(3):269-277

Goswami B, Mittal P, Gupta N (2013) Correlation of levels of IL-6 with tumor burden and receptor status in patients of locally advanced carcinoma breast. Indian J Clin Biochem 28(1):90-94

Heussen GA, Post JG, Alink GM (1990) Genotoxicity of benzo[a]pyrene, 2-nitrofluorene and airborne particulates in the DNA-repair host-mediated assay. Mutat Res 241(1):83-93

Hobisch A, Ramoner R, Fuchs D, Godoy-Tundidor S, Bartsch G, Klocker H, Culig Z (2001) Prostate cancer cells (LNCaP) generated after long-term interleukin 6 (IL-6) treatment express IL-6 and acquire an IL-6 partially resistant phenotype. Clin Cancer Res 7(9):2941-2948

Jiao H, Liu C, Guo W, Peng L, Chen Y, Martin FL (2010) Association of CYP1B1 polymorphisms with breast cancer: a case-control study in the han population in Ningxia Hui autonomous region, PR China. Biomark Insights 5:21-27

Kawai M, Malone KE, Tang MT, Li CI (2014) Active smoking and the risk of estrogen receptor-positive and triple-negative breast cancer among women ages 20-44 years. Cancer 120(7):1026-1034

Kazerouni N, Sinha R, Hsu CH, Greenberg A, Rothman N (2001) Analysis of 200 food items for benzo[a]pyrene and estimation of its intake in an epidemiologic study. Food Chem Toxicol 39(5):423-436

Knupfer H, Preiss R (2007) Significance of interleukin-6 (IL-6) in breast cancer (review). Breast Cancer Res Treat 102(2):129-135

Knupfer H, Schmidt R, Stanitz D, Brauckhoff M, Schonfelder M, Preiss R (2004) CYP2C and IL-6 expression in breast cancer. Breast 13(1):28-34

Kranendonk M, Mesquita P, Laires A, Vermeulen NP, Rueff J (1998) Expression of human cytochrome P450 1A2 in Escherichia coli: a system for biotransformation and genotoxicity studies of chemical carcinogens. Mutagenesis 13(3):263-269

Kurzawski M, Dziedziejko V, Post M, Wojcicki M, Urasinska E, Mietkiewski J, Drozdzik M (2012) Expression of genes involved in xenobiotic metabolism and transport in end-stage liver disease: up-regulation of ABCC4 and CYP1B1. Pharmacol Rep 64(4):927-939

Lauber SN, Gooderham NJ (2007) The cooked meat derived genotoxic carcinogen 2-amino-3-methylimidazo[4,5-b]pyridine has potent hormone-like activity: mechanistic support for a role in breast cancer. Cancer Res 67(19):9597-9602

Lauber SN, Gooderham NJ (2011) The cooked meat-derived mammary carcinogen 2-amino-1-methyl-6-phenylimidazo[4,5-b]pyridine promotes invasive behaviour of breast cancer cells. Toxicology 279(1-3):139-145
Lauber SN, Ali S, Gooderham NJ (2004) The cooked food derived carcinogen 2-amino-1-methyl-6-phenylimidazo[4,5-b] pyridine is a potent oestrogen: a mechanistic basis for its tissue-specific carcinogenicity. Carcinogenesis 25(12):2509-2517

Ley SH, Sun Q, Willett WC, Eliassen AH, Wu K, Pan A, Grodstein F, Hu FB (2014) Associations between red meat intake and biomarkers of inflammation and glucose metabolism in women. Am J Clin Nutr 99(2):352-360

Linos E, Holmes MD, Willett WC (2007) Diet and breast cancer. Curr Oncol Rep 9(1):31-41

Livak KJ, Schmittgen TD (2001) Analysis of relative gene expression data using real-time quantitative PCR and the 2(-Delta Delta C(T)) Method. Methods 25(4):402-408

Lu H, Ouyang W, Huang C (2006) Inflammation, a key event in cancer development. Mol Cancer Res 4(4):221-233

Lynch AM, Knize MG, Boobis AR, Gooderham NJ, Davies DS, Murray S (1992) Intra- and interindividual variability in systemic exposure in humans to 2-amino-3,8-dimethylimidazo[4,5-f]quinoxaline and 2-amino-1-methyl- 6-phenylimidazo[4,5-b]pyridine, carcinogens present in cooked beef. Cancer Res 52(22):6216-6223

Lynch AM, Gooderham NJ, Davies DS, Boobis AR (1998) Genetic analysis of PHIP intestinal mutations in MutaMouse. Mutagenesis 13(6):601-605

Malik DE, David RM, Gooderham NJ (2018a) Ethanol potentiates the genotoxicity of the food-derived mammary carcinogen PhIP in human estrogen receptor-positive mammary cells: mechanistic support for lifestyle factors (cooked red meat and ethanol) associated with mammary cancer. Arch Toxicol 92(4):1639-1655

Malik DE, David RM, Gooderham NJ (2018b) Mechanistic evidence that benzo[a]pyrene promotes an inflammatory microenvironment that drives the metastatic potential of human mammary cells. Arch Toxicol 92(10):3223-3239

Manabe S, Tohyama K, Wada O, Aramaki T (1991) Detection of a carcinogen, 2-amino-1-methyl-6-phenylimidazo[4,5-b]pyridine (PhIP), in cigarette smoke condensate. Carcinogenesis 12(10):1945-1947

Mantovani A, Allavena P, Sica A, Balkwill F (2008) Cancer-related inflammation. Nature 454(7203):436-444

McFadyen MCE, Melvin WT, Murray GI (2004) Cytochrome P450 enzymes: novel options for cancer therapeutics. Mol Cancer Ther 3(3):363-371

Morgan ET (1989) Suppression of constitutive cytochrome P-450 gene expression in livers of rats undergoing an acute phase response to endotoxin. Mol Pharmacol 36(5):699-707

Muntane-Relat J, Ourlin JC, Domergue J, Maurel P (1995) Differential effects of cytokines on the inducible expression of CYP1A1, CYP1A2, and CYP3A4 in human hepatocytes in primary culture. Hepatology 22(4 Pt 1):1143-1153

Murray S, Lynch AM, Knize MG, Gooderham MJ (1993) Quantification of the carcinogens 2-amino-3,8-dimethyl- and 2-amino-3,4,8trimethylimidazo[4,5-f]quinoxaline and 2-amino-1-methyl6-phenylimidazo[4,5-b]pyridine in food using a combined assay based on gas chromatography-negative ion mass spectrometry. $\mathrm{J}$ Chromatogr 616(2):211-219

Oh YS, Lee YJ, Park EY, Jun HS (2011) Interleukin-6 treatment induces beta-cell apoptosis via STAT-3-mediated nitric oxide production. Diabetes Metab Res Rev 27(8):813-819

Patel SA, Gooderham NJ (2015a) IL6 mediates immune and colorectal cancer cell cross-talk via miR-21 and miR-29b. Mol Cancer Res 13(11):1502-1508

Patel SAA, Gooderham NJ (2015b) Interleukin-6 promotes dietary carcinogen-induced DNA damage in colorectal cancer cells. Toxicol Res 4(4):858-866

Patel SA, Bhambra U, Charalambous MP, David RM, Edwards RJ, Lightfoot T, Boobis AR, Gooderham NJ (2014) Interleukin-6 mediated upregulation of CYP1B1 and CYP2E1 in colorectal 
cancer involves DNA methylation, miR27b and STAT3. Br J Cancer 111(12):2287-2296

Petrulis JR, Bunce NJ (1999) Competitive inhibition by inducer as a confounding factor in the use of the ethoxyresorufin- $O$-deethylase (EROD) assay to estimate exposure to dioxin-like compounds. Toxicol Lett 105(3):251-260

Pfeifer GP, Denissenko MF, Olivier M, Tretyakova N, Hecht SS, Hainaut P (2002) Tobacco smoke carcinogens, DNA damage and p53 mutations in smoking-associated cancers. Oncogene 21(48):7435-7451

Renton KW (2001) Alteration of drug biotransformation and elimination during infection and inflammation. Pharmacol Ther 92(2-3): 147-163

Renton KW (2004) Cytochrome $\mathrm{P} 450$ regulation and drug biotransformation during inflammation and infection. Curr Drug Metab 5(3):235-243

Rieger JK, Reutter S, Hofmann U, Schwab M, Zanger UM (2015) Inflammation-associated microRNA-130b down-regulates cytochrome P450 activities and directly targets CYP2C9. Drug Metab Dispos 43(6):884-888

Rodriguez-Antona C, Ingelman-Sundberg M (2006) Cytochrome P450 pharmacogenetics and cancer. Oncogene 25(11):1679-1691

Ronco AL, De Stefani E, Correa P, Deneo-Pellegrini H, Boffetta P, Acosta G, Mendilaharsu M (2011) Dietary benzo[a]pyrene, alcohol drinking, and risk of breast cancer: a case-control study in Uruguay. Asian Pac J Cancer Prev 12(6):1463-1467

Safe S, Lee S-O, Jin U-H (2013) Role of the aryl hydrocarbon receptor in carcinogenesis and potential as a drug target. Toxicol Sci 135:1-16

Sanguinetti A, Santini D, Bonafe M, Taffurelli M, Avenia N (2015) Interleukin- 6 and pro inflammatory status in the breast tumor microenvironment. World J Surg Oncol 13:129

Shi Q, Boots AW, Maas L, Veith C, van Kuijk K, Haenen GR, Godschalk RW, Van Schooten FJ (2017) Effect of interleukin (IL)-8 on benzo[a]pyrene metabolism and DNA damage in human lung epithelial cells. Toxicology 381:64-74

Shivappa N, Sandin S, Lof M, Hebert JR, Adami HO, Weiderpass E (2015) Prospective study of dietary inflammatory index and risk of breast cancer in Swedish women. Br J Cancer 113(7):1099-1103

Siewert E, Bort R, Kluge R, Heinrich PC, Castell J, Jover R (2000) Hepatic cytochrome P450 down-regulation during aseptic inflammation in the mouse is interleukin 6 dependent. Hepatology 32(1):49-55

Sinha R, Rothman N (1999) Role of well-done, grilled red meat, heterocyclic amines (HCAs) in the etiology of human cancer. Cancer Lett 143(2):189-194

Stenvang J, Petri A, Lindow M, Obad S, Kauppinen S (2012) Inhibition of microRNA function by antimiR oligonucleotides. Silence $3: 1$

Strom S, Michalopoulos G (1982) Mutagenesis and DNA binding of benzo(a)pyrene in cocultures of rat hepatocytes and human fibroblasts. Cancer Res 42(11):4519-4524
Ueno T, Toi M, Saji H, Muta M, Bando H, Kuroi K, Koike M, Inadera H, Matsushima K (2000) Significance of macrophage chemoattractant protein-1 in macrophage recruitment, angiogenesis, and survival in human breast cancer. Clin Cancer Res 6(8):3282-3289

Umannova L, Machala M, Topinka J, Novakova Z, Milcova A, Kozubik A, Vondracek J (2008) Tumor necrosis factor-alpha potentiates genotoxic effects of benzo[a]pyrene in rat liver epithelial cells through upregulation of cytochrome P450 1B1 expression. Mutat Res 640(1-2):162-169

Willett WC (2000) Diet and cancer. Oncologist 5(5):393-404

Winton DJ, Gooderham NJ, Boobis AR, Davies DS, Ponder BA (1990) Mutagenesis of mouse intestine in vivo using the Dlb-1 specific locus test: studies with 1,2-dimethylhydrazine, dimethylnitrosamine, and the dietary mutagen 2-amino-3,8-dimethylimidazo[4,5f]quinoxaline. Cancer Res 50(24):7992-7996

Wu AH, Yu MC, Tseng CC, Stanczyk FZ, Pike MC (2009) Dietary patterns and breast cancer risk in Asian American women. Am J Clin Nutr 89(4):1145-1154

Yadollahi-Farsani M, Gooderham NJ, Davies DS, Boobis AR (1996) Mutational spectra of the dietary carcinogen 2-amino-1-methyl-6phenylimidazo[4,5-b]pyridine( $\mathrm{PhIP})$ at the Chinese hamsters hprt locus. Carcinogenesis 17(4):617-624

Yamashita J, Ogawa M, Nomura K, Matsuo S, Inada K, Yamashita S, Nakashima Y, Saishoji T, Takano S, Fujita S (1993) Interleukin 6 stimulates the production of immunoreactive endothelin 1 in human breast cancer cells. Cancer Res 53(3):464-467

Zhang GJ, Adachi I (1999) Serum interleukin-6 levels correlate to tumor progression and prognosis in metastatic breast carcinoma. Anticancer Res 19(2b):1427-1432

Zhao K, Murray S, Davies DS, Boobis AR, Gooderham NJ (1994) Metabolism of the food derived mutagen and carcinogen 2-amino1-methyl-6-phenylimidazo(4,5-b)pyridine ( $\mathrm{PhIP})$ by human liver microsomes. Carcinogenesis 15(6):1285-1288

Zheng W, Lee SA (2009) Well-done meat intake, heterocyclic amine exposure, and cancer risk. Nutr Cancer 61(4):437-446

Zhu J, Chang P, Bondy ML, Sahin AA, Singletary SE, Takahashi S, Shirai T, Li D (2003) Detection of 2-amino-1-methyl6-phenylimidazo[4,5-b]-pyridine-DNA adducts in normal breast tissues and risk of breast cancer. Cancer Epidemiol Biomarkers Prev 12(9):830-837

Publisher's Note Springer Nature remains neutral with regard to jurisdictional claims in published maps and institutional affiliations. 